\title{
Atmospheric Circulation Changes in the Tropical Pacific Inferred from the Voyages of the Manila Galleons in the Sixteenth- Eighteenth Centuries
}

\author{
Rolando R. Garcia, ${ }^{*}$ Henry F. Díaz,+ Ricardo García Herrera," Jon Eischeid,+ \\ María del Rosario Prieto, ${ }^{\circledR}$ Emiliano Hernández," Luis Gimeno, ${ }^{\&}$ \\ Francisco Rubio Durán, ${ }^{* *}$ and Ana María Bascary**
}

\begin{abstract}
Historical accounts of the voyages of the Manila galleons derived from the Archivo General de Indias (General Archive of the Indies, Seville, Spain) are used to infer past changes in the atmospheric circulation of the tropical Pacific Ocean. It is shown that the length of the voyage between Acapulco, Mexico, and the Philippine Islands during the period 1590-1750 exhibits large secular trends, such that voyages in the middle of the seventeenth century are some $40 \%$ longer than those at the beginning or at the end of the century, and that these trends are unlikely to have been caused by societal or technological factors. Analysis of a series of "virtual voyages," constructed from modern wind data, indicates that sailing time to the Philippines depended critically on the strength of the trade winds and the position of the western Pacific monsoon trough. These results suggest that the atmospheric circulation of the western Pacific underwent large, multidecadal fluctuations during the seventeenth century.
\end{abstract}

\section{Introduction}

The use of historical records as proxies for climate has gained wide acceptance in recent years (Bradley and Jones 1992). These proxies can provide data of high quality at high temporal resolution, and they have been used to characterize the variability of circulation patterns, such as those that accompany El Niño-Southern Oscillation events (e.g., Quinn

\footnotetext{
*National Center for Atmospheric Research, Boulder, Colorado. ${ }^{+}$Climate Diagnostics Center, NOAA, Boulder, Colorado.

"Universidad Complutense, Madrid, Spain.

${ }^{\circledR}$ CRICYT, Mendoza, Argentina.

\&Universidad de Vigo, Orense, Spain.

**Universidad de Sevilla, Seville, Spain.

Corresponding author address: Dr. Rolando R. García, Atmospheric Chemistry Division, National Center for Atmospheric Research, P.O. Box 3000, Boulder, CO 80307-3000.

E-mail: rgarcia@ncar.ucar.edu

In final form 25 May 2001.

(C2001 American Meteorological Society
}

et al. 1978; Quinn 1992; Ortlieb 2000; Prieto et al. 1999). The work of Quinn and coworkers, in particular, highlighted the usefulness of historical proxies derived from Spanish America, where European settlement dates back to the late sixteenth century.

In the present study we exploit a relatively unexplored source of historical data, the Archivo General de Indias (General Archive of the Indies; hereafter denoted by its initials, AGI). The AGI is the central repository for documents related to the colonial administration of Spanish America. It was founded in the late eighteenth century, during the reign of Carlos III, to house scattered collections of documents, as well as material previously stored in the National Archive at Simancas, in Valladolid. The Lonja de Mercaderes (Merchants' Meeting House) of Seville, was refurbished to house the new collection, a fitting choice since the Lonja served as headquarters for much of the commercial activity between Spain and the New World during the seventeenth and early eighteenth centuries. The first papers were received in 
Seville in 1785; the collection has since grown to over 80 million pages of original writings, encompassing all aspects of military, commercial, and cultural relations between Spain and its American colonies. An overview of the potential uses of the AGI for climatological studies can be found in García Herrera et al. (1999).

We have searched the AGI for documentation related to the voyages of the "Manila galleons," the name given to the ships that carried on the longest continuous commercial route in recorded history. For 250 years (1565-1815) usually one ship, and often several, sailed from the Philippine capital of Manila in July of each year, arriving in Acapulco, Mexico, five to six months later. On the eastward voyage the ships traveled north from the Philippines to the vicinity of southern Japan, in search of the Kuro-Shio current $^{1}$ and favorable westerly winds. On the much faster westward voyage, the ships left Acapulco toward the end of March, sailing with the northeast trades near $12^{\circ} \mathrm{N}$, and arrived in Manila in late June or early July. The voyages had a dual purpose: sailing from Manila, the galleons carried a cargo of luxury goods from the Far East (silks, porcelain, jewelry), which could be sold at a handsome profit in the market fair held in Acapulco in February. On the westward voyage, the ships carried silver (the proceeds of sales at the Acapulco fair, plus the annual Crown subsidy to the Philippine colony), soldiers to man the garrison at Manila, missionary priests and members of religious orders, and a variable number of civilian passengers and administrative personnel posted to Manila. A thorough description of the Manila trade can be found in Schurz (1939); a lively short account is that of Williams (1982).

The motivation for our study was the possibility that records of these voyages might provide information on the circulation of the tropical Pacific. The ideal source for this purpose are the ships' logs, where information on wind, ocean currents, and weather are usually recorded. Although previous work by Burt (1990) suggested that few logbooks are extant, we nevertheless attempted to locate any that might have been missed. Our search confirmed Burt's findings; in all, we were able to find just two additional log-

\footnotetext{
${ }^{1}$ Although the sailors of the Manila trade probably took advantage of the Kuro-Shio for the Manila-Acapulco voyage, it is not at all clear whether they had anything like a modern conception of this current system.
}

books, for the years 1770 (AGI, Filipinas 938) and 1781 (AGI, Guadalajara 520). ${ }^{2}$

We did, however, find abundant documentation concerning the arrival and departure dates of the galleons, for both Acapulco and Manila. These dates were used to construct a series of the duration of the voyage from the late sixteenth through the mideighteenth century. The eastward (Manila to Acapulco) route was influenced by several variables, such as the strength of the midlatitude westerlies and the incidence of typhoons in the western Pacific. On the other hand, the westward (Acapulco to Manila) voyage was made under the influence of the northeast trades, so it was hypothesized that its duration would be an indicator of the steadiness and intensity of the trades. Indeed, we found that this time series exhibits large, multidecadal trends that are unlikely to be caused by extraneous factors such as changes in route, cargo, or ship design. We show that these trends may reflect real, long-term changes in the atmospheric circulation over the tropical Pacific Ocean during the period in question.

\section{Documenting the Acapulco-Manila voyage}

\section{a. The AGI collection}

The AGI collection is divided into "sections", each one covering a different area of colonial affairs. Table 1 shows the current organization of the AGI, together with the number of legajos, or manuscript bundles, contained in each section and the range of dates covered. Each legajo consists of a group of related documents and averages some 1500-2000 manuscript pages. The source data for the present study are those documents containing references to the departure date of the Manila galleons from Acapulco, the arrival date in Manila, and any information on dates and locations of intermediate stops. The majority of such references were found in the sections of Contaduría (accounting), Contratación (contracts), Estado (state), Gobierno (administration), and Patronato (royal patronage). The section of Gobierno

\footnotetext{
${ }^{2}$ References to manuscript sources in the Archivo General de Indias are denoted by the initials AGI, followed by the name of the section of the archive where the manuscript is located, and a number identifying the legajo, or bundle, to which the manuscript belongs. See section 2 of this paper for details on the archive's system of manuscript classification and indexing.
} 
holds by far the largest number of documents and is categorized further according to the administrative subdivisions of the Spanish colonies; within Gobierno, the subsections of Mexico, Filipinas, and Indiferente General (general miscellaneous) yielded the greatest quantity of relevant materials.

Over 1000 documents containing information on the voyages of the Manila galleons were identified in our searches of the AGI, and the relevant passages were excerpted and transcribed. These documents mention 220 voyages from Acapulco to Manila. They include the 1564 voyage of Miguel López de Legazpi, who founded Manila, and actually returned to Mexico in 1565. Before Legazpi's voyage, attempts to make the eastward crossing of the Pacific had all ended in failure, the ships either being lost or forced to turn back. Legazpi's accomplishment- the first recorded transpacific round trip, spanning some $25000 \mathrm{~km}$ - owed much to the experience of Fray Andrés de Urdaneta, a former mariner turned Augustinian friar, who served as a pilot in Legazpi's expedition and devised the eastward route that was to be followed for the next 250 years (the last galleon arrived in Mexico in 1815, a few years before the colony became independent of Spain).

\section{b. The Acapulco-Manila voyage}

The typical westward voyage usually left Acapulco in the last half of March, sometime after the Acapulco fair. The latter was held in February, and while it lasted, the population of Acapulco, otherwise a poor and rather isolated small village, more than doubled. Merchants from all over Mexico, and also from as far as Lima, Peru, came to Acapulco to trade for the oriental merchandise brought by the galleon from Manila (which would normally arrive in port sometime between November of the previous year and February, depending on the highly variable weather conditions encountered on the eastward voyage).

After leaving Acapulco $\left(16^{\circ} 51^{\prime} \mathrm{N}, 99^{\circ} 55^{\prime} \mathrm{W}\right)$, the galleons proceeded $\mathrm{SW}$ to the vicinity of $12^{\circ} \mathrm{N}$, and continued west near that latitude ${ }^{3}$ to the Embocadero de San Bernardino (Strait of San Bernardino; $12^{\circ} 32^{\prime} \mathrm{N}$, $\left.124^{\circ} 10^{\prime} \mathrm{E}\right)$, where the ships entered the inland waters of the Philippine archipelago for the final leg to Manila $\left(14^{\circ} 35^{\prime} \mathrm{N}, 121^{\circ} \mathrm{E}\right)$. As an example, the course followed by the galleon San Pedro in 1779 is shown in Fig. 1. Position data are taken from the ship's log,

\footnotetext{
${ }^{3}$ Most voyages for which we have found a description of the route crossed the Pacific between $10^{\circ}$ and $15^{\circ} \mathrm{N}$.
}

which begins at Acapulco on 11 March and ends at the Embocadero on 5 June. Other sources for the voyage state that the ship arrived at Cavite (Manila's harbor) on 16 June, 11 days after entering the strait.

From the Embocadero the ships sailed generally west past the north end of the island of Masbate, then northwest to the northwestern tip of Mindoro, finally turning north for the run into Cavite. Figure 2 shows a map of the typical route. Not infrequently the ships were forced to put in at one of a number of ports near the Embocadero to resupply, perform repairs, or await favorable winds to enter the strait. If the ship arrived at the Embocadero after the end of June, it was often impossible to proceed to Manila because of the adverse winds of the summer monsoon. In such cases,

TABLE 1. Organization and holdings of the Archivo General de Indias.

\begin{tabular}{|c|c|c|}
\hline Section & Dates & $\begin{array}{l}\text { Number of } \\
\text { legajos held }\end{array}$ \\
\hline 1) Patronato & $1480-1790$ & 306 \\
\hline 2) Contaduría & $1514-1778$ & 2126 \\
\hline 3) Contratación & $1492-1794$ & 6335 \\
\hline 4) Justicia & $1515-1600$ & 1214 \\
\hline 5) Gobierno & $1492-1858$ & 18760 \\
\hline 6) Escribanía & $1525-1760$ & 2864 \\
\hline 7) Secretaría & $1674-1822$ & 648 \\
\hline 8) Correos & $1620-1846$ & 895 \\
\hline 9) Estado & $1642-1830$ & 110 \\
\hline 10) Ultramar & $1605-1870$ & 1013 \\
\hline 11) Cuba & $1712-1872$ & 2967 \\
\hline 12) Consulados & $1520-1870$ & $1903 *$ \\
\hline 13) Títulos de Castilla & $1700 s-1800 s$ & 14 \\
\hline 14) Tribunal de Cuentas & $1851-99$ & 2751 \\
\hline 15) Diversos & $1492-1898$ & 48 \\
\hline 16) Mapas y Planos & $1500 \mathrm{~s}-1800 \mathrm{~s}$ & 6457 \\
\hline
\end{tabular}

*Plus 1255 bound volumes. 


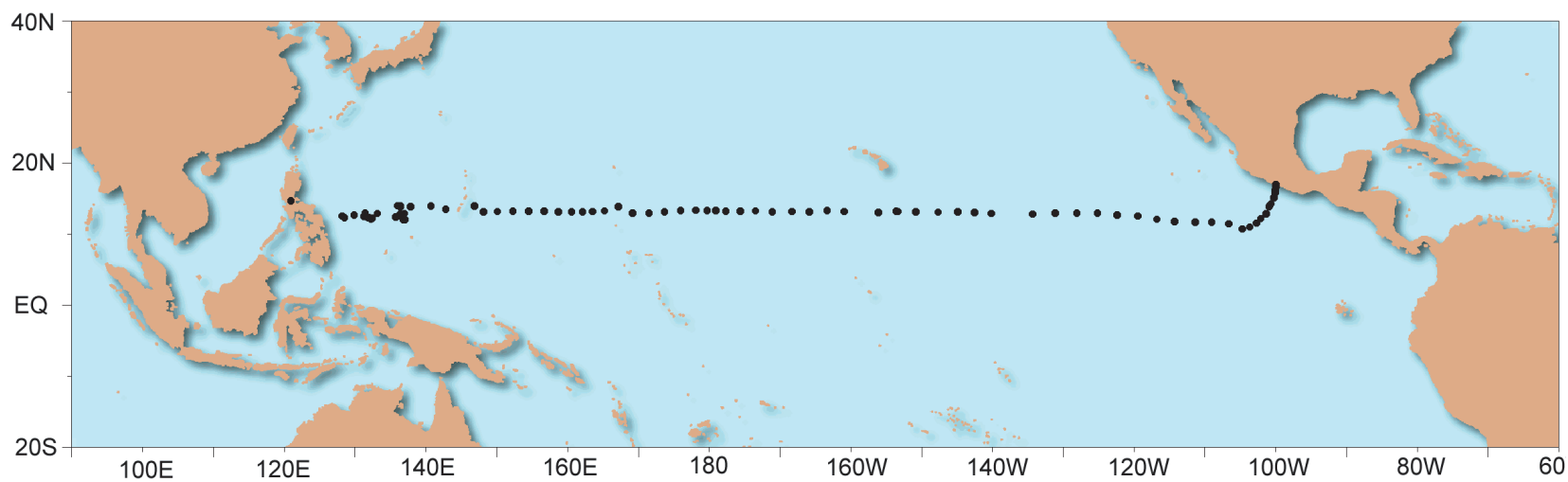

FIG. 1. Route from Acapulco to the Embocadero. Ship position data (at 1-day intervals) are taken from the logbook of the galleon San Pedro, which made the voyage in 1779 (AGI, Filipinas 975).

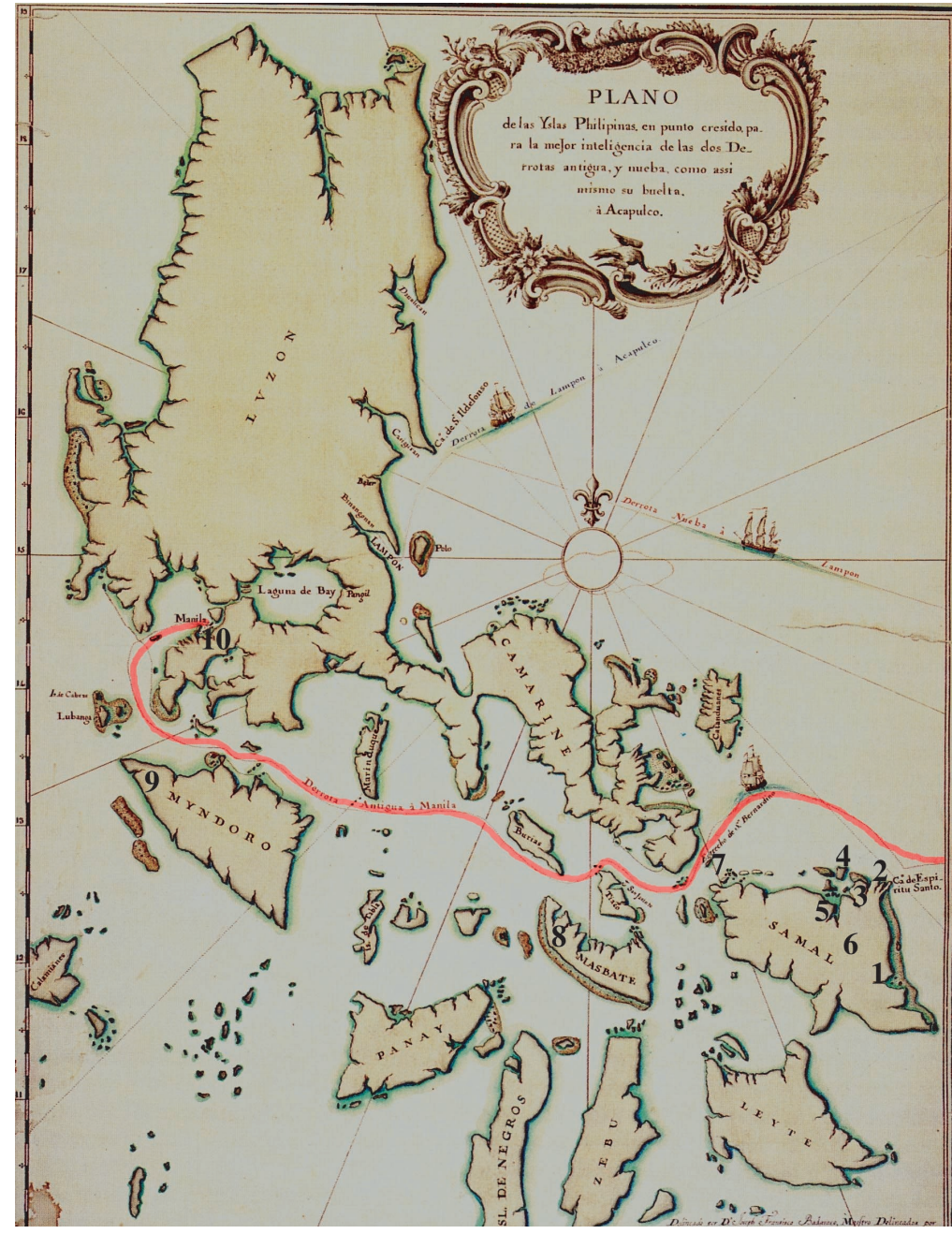

FIG. 2. Map of the Philippines with the approximate route (in red) followed by the galleons from the Strait of San Bernardino to Manila. Adapted from a map by J. F. de Badaraco, Museo Naval de Madrid. Several locations of importance to the Acapulco-Manila trip are indicated: 1) Borongo (Borongan); 2) Cape Espíritu Santo; 3) Palapa (Palapag); 4) Lyam, or Luyam (Laoang); 5) Cagayán, or Cajagayán; 6) Samar Island; 7) Embocadero (Strait of San Bernardino); 8) Masbate Island; 9) Mindoro Island; and 10) Manila. the ship remained in port outside the Embocadero until the end of the monsoon season, passengers and silver proceeding by land to Manila. This issue is addressed in some detail by Schurz (1939).

\section{c. Documentation relevant to the voyages}

Among the Acapulco-Manila voyages documented in the AGI, departure and arrival dates were identified for more than 150 voyages, spanning the period 1591-1802. Although most of these voyages are unambiguously dated, a substantial fraction present difficulties in that 1) the arrival date is approximate, or 2) the arrival date found is not for the port of Manila, but for one of several locations near the Strait of San Bernardino. Table 2 illustrates these points by means of a few excerpts from AGI documents. Voyages like that of 1591 present no problems of interpretation. On the other hand, the voyage of 1625 has no arrival date for the Santísima Trinidad, ${ }^{4}$ while the arrival date of the

${ }^{4}$ Not to be confused with the 2000-ton galleon captured by a British force under Admiral Thomas Cavendish in 1762, during the Seven Years' War. Nonetheless, losses to the enemy were a negligible risk in the Manila trade; according to Schurz (1939), just four ships were captured during the 250 years that the route was maintained. A far greater hazard was storms, especially on the Manila to Acapulco voyage. 
TABLE 2. Sample excerpts from AGI documents relating to the Manila galleons.

\begin{tabular}{|c|c|c|c|c|}
\hline Year & Ship name & $\begin{array}{c}\text { Departure } \\
\text { date }\end{array}$ & $\begin{array}{c}\text { Arrival } \\
\text { date }\end{array}$ & References \\
\hline 1591 & $\begin{array}{l}\text { Santiago } \\
\text { San Ildefonso }\end{array}$ & $\begin{array}{l}25 \mathrm{Mar} \\
25 \mathrm{Mar}\end{array}$ & $\begin{array}{l}21 \text { Jun } \\
\text { lost }\end{array}$ & $\begin{array}{l}\text { Mexico 22, N11 and N46: both ships departed together } \\
\text { on } 25 \text { Mar; the governor's ship [Santiago] arrived "after a } \\
\text { reasonably good voyage." The San Ildefonso was lost at sea } \\
\text { Contaduría 1202: the galleon Santiago arrived at Cavite on } \\
21 \text { Jun } 1591\end{array}$ \\
\hline 1625 & $\begin{array}{l}\text { Nuestra Señora de } \\
\text { Atocha }\end{array}$ & $6 \mathrm{Apr}$ & $<1$ Aug $^{\mathrm{a}}$ & 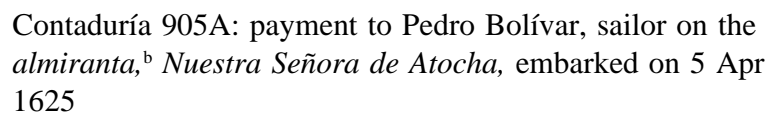 \\
\hline & Santísima Trinidad & $6 \mathrm{Apr}$ & Unknown & $\begin{array}{l}\text { Contaduría 904: The almiranta and capitana left for Cavite } \\
\text { on } 6 \text { Apr 1625; the capitana was the Santísima Trinidad } \\
\text { and the almiranta, the Nuestra Señora de Atocha } \\
\text { Filipinas 30: [letter from] the royal officers of the } \\
\text { Philippines to the king of Spain, } 1 \text { Aug } 1625: \text { "By the ship } \\
\text { Atocha we have received your letters. ..." }\end{array}$ \\
\hline 1689 & $\begin{array}{l}\text { Santo Cristo de } \\
\text { Burgos }\end{array}$ & $31 \mathrm{Mar}$ & $\begin{array}{l}25 \mathrm{Jun}^{\mathrm{c}} \\
19 \mathrm{Jul}^{\mathrm{c}}\end{array}$ & $\begin{array}{l}\text { Contaduría } 906 \text { B: reports departure of the Santo Cristo de } \\
\text { Burgos from Acapulco, and arrival at the port of Palapac } \\
\text { after a voyage of } 86 \text { days } \\
\text { Mexico 59, R3, N6: "The galleon Santo Cristo de } \\
\text { Burgos . . arrived in Cavite on } 19 \text { July ... It [previously] } \\
\text { arrived at Palapa in } 86 \text { days" }\end{array}$ \\
\hline 1734 & $\begin{array}{l}\text { Nuestra Señora de } \\
\text { Covadonga }\end{array}$ & 9 Apr & $<14$ Aug $^{\mathrm{d}}$ & $\begin{array}{l}\text { Filipinas 738: } 14 \text { Aug } 1734-\text { Crown subsidy deposited [in } \\
\text { the Manila treasury] "by sgt. major Antonio García de } \\
\text { Mazo, master of the Nuestra Señora de Covandonga, } \\
\text { arrived from New Spain" [i.e., Mexico] }\end{array}$ \\
\hline
\end{tabular}

\footnotetext{
${ }^{a}$ The precise date of arrival is unknown. The source quoted (Filipinas 30) is a letter, dated 1 Aug 1625, acknowledging that royal correspondence sent on the Atocha was received in Manila.

${ }^{\mathrm{b}}$ In years when more than one ship made the voyage, the capitana was the flagship of the convoy; the almiranta was the second in command.

${ }^{\mathrm{c}}$ The date of arrival at Palapa is 25 Jun, after 86 days of sailing, according to Contaduría 906; Palapa (modern Palapang, $12^{\circ} 33^{\prime} \mathrm{N}, 125^{\circ} 07^{\prime} \mathrm{E}$ ) is a port east of the Strait of San Bernardino. The date of arrival in Manila's port of Cavite is 19 Jul.

d The precise date of arrival is unknown. The source from Filipinas 738 records the deposit of the Crown subsidy to the Manila colony.
}

Atocha is uncertain because the only reference found was a letter dated 1 August 1625, acknowledging the receipt of the royal correspondence aboard the Atocha. Such evidence postdates the arrival of the ship by an unknown length of time. Note also that a couple of references to payment of crew members before com- ing aboard are dated 5 April rather than the actual departure date of 6 April. Such references are frequent, and sometimes they are the only ones available for dating the departure of the galleon. In general, they do not present a major difficulty, as the date of embarkation usually precedes that of sailing by no more than 
a few days. A more serious problem occurs with the voyage of 1734 , for which the only indication of arrival is a report of the deposit of the Crown subsidy carried by the Nuestra Señora de Covandonga. Finally, the voyage of 1689 is especially informative in that it provides the date of arrival at both Manila (19 Jul) and Palapa (25 Jun), a port near the Embocadero de San Bernardino. Many documents provide a date of arrival at the Embocadero, but not at Manila, so an estimate of the average transit time for the Embocadero-Manila leg is extremely useful, as we shall see later on.

\section{Data selection}

The examples given in Table 2 illustrate the types of problems encountered when interpreting the historical references for the Acapulco-Manila trip. Clearly, the data cannot be used without further scrutiny in all cases. In what follows we summarize the procedure employed to screen the original references and standardize the duration of the voyages.

\section{a. Imprecise arrival dates}

Lack of precision in the arrival date introduces a systematic error in the estimates of voyage duration. Imprecise arrival dates occur mainly when the date of deposit of the Crown subsidy in the Manila treasury is known, but not the actual arrival date (e.g., the voyage of 1625 in Table 2). It is possible to gain some idea of the error involved by examining those trips for which both the precise date of arrival and the date of deposit of the subsidy are available. We found 26 such trips, which show a range of 4 to 147 days in the interval between the two events; however, in none of the years when the voyage terminated in Manila was the interval greater than a few days. Large differences between arrival and deposit of the subsidy appear to occur in years when the ship remained at a port near the Embocadero and the subsidy was brought to Manila by land. Thus, the date of deposit of the subsidy is a reasonably good indicator of the date of arrival if the trip terminated in Manila. Of 15 trips for which the only evidence of arrival was the deposit of the subsidy, we have retained 9 that are known to have ended in Manila; we have not otherwise adjusted their arrival dates.

The other major source of uncertainty in arrival dates occurs when the evidence consists of a letter noting the arrival of the ship, but without an explicit statement of the date (e.g., the 1734 voyage in Table 2). There were 13 trips for which such letters are the only indication of arrival, and a few more for which the sources include both a letter and another, unambiguous reference. From the latter we know that letters were usually written within a few days of the ship's arrival since they were meant to be carried to Mexico via the eastbound galleon, which sailed shortly after the arrival of the westbound one. We have retained all 13 voyages whose arrival at Manila is dated by letters, without adjusting the dates.

\section{b. Arrivals at ports other than Manila}

Manila-bound ships often stopped at various locations near the Embocadero de San Bernardino to perform repairs, obtain provisions, or await favorable winds for the trip to Manila through the waters of the Philippine archipelago. On occasion, if the ship arrived after the monsoon was well established, it might be impossible to proceed to Manila, in which case the ships were unloaded and the cargo and passengers went on to the city by land. There are several voyages for which both the date of arrival at the Embocadero and the date of arrival at Manila are known. As shown in Table 3, the mean of these voyages is 18.2 days. A few more voyages list the date of arrival at Guam, in the Marianas $\left(13^{\circ} 28^{\prime} \mathrm{N}, 144^{\circ} 47^{\prime} \mathrm{E}\right)$, as well as the date of arrival at the Embocadero (Table 4); they yield a mean of 16 days for the Guam-Embocadero voyage. These estimates are consistent with the account of the westward voyage given by Schurz (1939), who states that each of these legs took about 15 days. There are 33 voyages with arrival dates only at Guam or at the Embocadero. In order to "standardize" our data, we have calculated the travel time to the Embocadero for all voyages by subtracting 18.2 days from the trips ending in Manila, and adding 16 days to the trips whose arrival date is only known for Guam. We have chosen the duration of the voyage to the Embocadero, rather than to Manila, in order to facilitate comparison with travel times estimated from modern wind data, as discussed in section 6 .

Table 5 summarizes our treatment of the raw data from the AGI. Of the 141 voyages accepted after screening for unreliable arrival dates, 84 voyages $(60 \%$ of the total) are based on references that we considered unambiguous; an additional 35 voyages provided data that were corrected, as discussed above, to give the arrival date in Manila; arrival information for 13 voyages is based upon the date of a letter that mentions the ship's arrival at Manila; and an additional 9 
TABle 3. Dates of arrival at the Strait of San Bernardino (or vicinity) and Manila.

\begin{tabular}{cccc}
\hline \hline Year & $\begin{array}{c}\text { Arrival at } \\
\text { San Bernardino }\end{array}$ & $\begin{array}{c}\text { Arrival at } \\
\text { Manila }\end{array}$ & $\begin{array}{c}\text { Interval } \\
\text { (days) }\end{array}$ \\
\hline 1594 & 10 Jun & 15 Jun & 5 \\
\hline 1603 & 1 Jun & 24 Jun & 23 \\
\hline 1603 & 1 Jun & 22 Jun & 21 \\
\hline 1605 & 11 Jun & 17 Jun & 6 \\
\hline 1672 & 20 May & 10 Jun & 20 \\
\hline 1685 & 15 Jun & 5 Jul & 20 \\
\hline 1721 & 25 Jun & 19 Jul & 24 \\
\hline 1729 & 7 Jul & 20 Jul & 13 \\
\hline 1 Jul & 5 Jun & 16 Jun & 11 \\
\hline
\end{tabular}

voyages have arrival dates estimated from the date of the deposit of the Crown subsidy in Manila. The data for 16 voyages were rejected. In six of these cases the arrival reference was the deposit of the subsidy, which took place so late in the year as to suggest that the galleon had been forced to seek port near the Embocadero, and the subsidy had been brought overland to Manila. An additional 10 voyages were rejected for miscellaneous unclear references to either the departure or arrival date. These numbers appear in Table 5 in the row labeled subtotal. An additional 20 voyages, which took place after 1750 , were eliminated for reasons explained in section 4, even though their arrival and departure dates were otherwise acceptable.

\section{Extraneous influences on voyage duration}

In addition to the quality control issues discussed above, it is necessary to examine human and technological factors that may have influenced the duration of the voyage. This is important because the time series of voyage duration must be homogeneous if it is
TABle 4. Dates of arrival at Guam (Marianas) and at San Bernardino (or vicinity)

\begin{tabular}{cccc}
\hline \hline Year & $\begin{array}{c}\text { Arrival at } \\
\text { Guam }\end{array}$ & $\begin{array}{c}\text { Arrival at } \\
\text { San Bernardino }\end{array}$ & $\begin{array}{c}\text { Interval } \\
\text { (days) }\end{array}$ \\
\hline 1601 & 19 Apr & 1 May & 12 \\
\hline 1672 & 2 May & 20 May & 18 \\
\hline 1688 & 2 Jun & 30 Jun & 28 \\
1721 & 23 Jun & 7 Jul & 14 \\
1743 & 16 Jun & 30 Jun & 14 \\
\hline 1779 & 1 Mar & 11 Mar & 10 \\
\hline Mean & & & 16.0 \\
\hline
\end{tabular}

to be used as a proxy for atmospheric variability. While it is impossible to be certain that all spurious factors influencing voyage duration have been considered, we attempt next to show that the most obvious candidates are unlikely to pose very serious problems.

TABle 5. Treatment of the data, Acapulco-Manila voyage.

\begin{tabular}{lcc}
\hline \multicolumn{1}{c}{$\begin{array}{c}\text { Type of } \\
\text { reference }\end{array}$} & $\begin{array}{c}\text { No. } \\
\text { accepted }\end{array}$ & $\begin{array}{c}\text { No. } \\
\text { rejected }\end{array}$ \\
\hline $\begin{array}{l}\text { Unambiguous or minor } \\
\text { ambiguity }\end{array}$ & 84 & 0 \\
\hline $\begin{array}{l}\text { Arrival at Embocadero or } \\
\text { at Guam }\end{array}$ & 35 & 0 \\
\hline $\begin{array}{l}\text { Date of letter mentioning } \\
\text { arrival }\end{array}$ & 13 & 0 \\
$\begin{array}{l}\text { Date of deposit of Crown } \\
\text { subsidy }\end{array}$ & 9 & 6 \\
\hline $\begin{array}{l}\text { Miscellaneous ambiguous } \\
\text { references }\end{array}$ & 0 & 10 \\
\hline $\begin{array}{l}\text { Subtotal } \\
\text { Voyages after 1750 }\end{array}$ & 141 & 20 \\
\hline \begin{tabular}{l} 
Total \\
\hline
\end{tabular} & 0 & 36 \\
\hline
\end{tabular}




\section{a. Starting date of the voyage}

The starting date of the voyage must be taken into account because the wind system of the tropical $\mathrm{Pa}$ cific changes seasonally. The northeast trades, which the galleons used on the westward voyage, blow most strongly during the months of March through May; in the western Pacific, the Southeast Asian monsoon begins to dominate the circulation in May, strengthens and becomes more regular in June, and reaches its maximum intensity in July and August (Ramage 1971; McGregor and Nieuwolt 1998). A ship approaching the Philippines in June would generally enjoy easier westward sailing than one arriving in July, when monsoon winds are more intense. As noted earlier, late arrivals often were forced to put into ports near the Embocadero, the winds being unfavorable for navigating the inland waters of the Philippine archipelago.

Figure 3 shows the time series of starting dates for the voyage, based on the 141 Acapulco-Manila trips selected earlier. Starting dates cluster about the last three weeks of March and first week of April; in fact, 118 of the 141 voyages have starting dates between Julian days 70 (11 Mar) and 100 (11 Apr). In the 179 years between 1591 and 1770 there are just 15 voyages that started outside this range and, except for the voyages of 1609 and 1742, all voyages began either in February or March. The 1742 voyage is an exception that proves the rule: according to AGI documents (Filipinas 255), the Nuestra Señora del Pilar was scheduled to sail on 20 March, but its departure was delayed until 7 December because a squadron of British ships ${ }^{5}$ had been operating near Acapulco.

On the other hand, between 1770 and the end of the series in 1802, there are several voyages that depart at unusual times. In addition, after 1770 there seems to be a trend toward earlier starting dates (by 1800 , voyages start near the end of February). Several of these eighteenth century voyages were not undertaken as part of the Manila trade; for example, the ship departing on 18 December 1779 was a packetboat sent expressly by the Viceroy of New Spain (i.e., Mexico), possibly for the purpose of carrying official mail to Manila (AGI, Filipinas 497). Similarly, on 25 Decem-

\footnotetext{
${ }^{5}$ The squadron was under the command of Commodore George Anson, and the incident was part of the War of the Austrian Succession. Anson later set sail for the Philippines where, on 30 June 1743, he captured the Nuestra Señora de Covadonga, which had left Acapulco on 15 April of that year. Schurz (1939) tells the complete story.
}

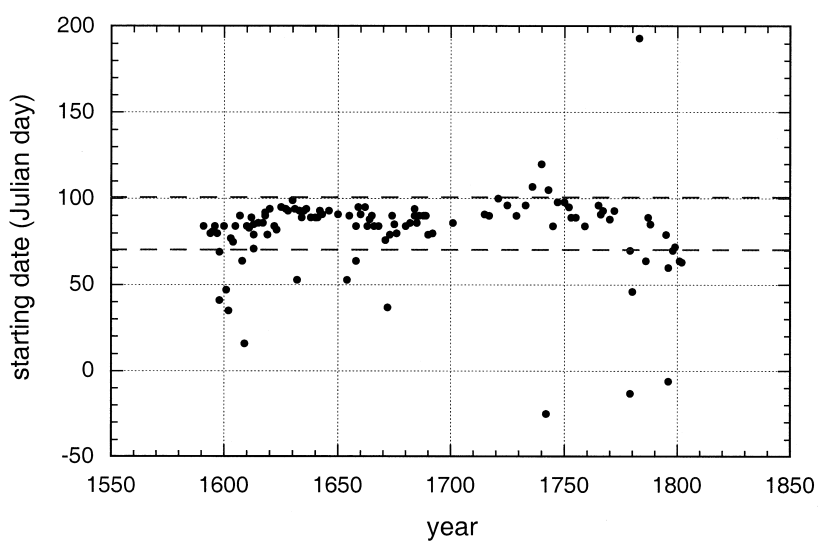

FIG. 3. Starting date (Julian day) for Acapulco-Manila voyages, 1591-1802. The dashed lines indicate Julian days 70 (11 Mar) and 100 (11 Apr). Negative starting dates refer to the previous year; thus, day -10 is 21 Dec.

ber 1796, the brigantine Activo, a navy ship, left the port of San Blas $\left(21^{\circ} 31^{\prime} \mathrm{N}, 105^{\circ} 16^{\prime} \mathrm{W}\right)$, north of Acapulco, carrying mail and a notice that the frigate San Andrés - presumably the actual Manila trade ship—would leave for Manila in January 1797 (AGI, Estado 46, N24 and N45). These considerations suggest that voyages after 1770 should not be included in the analysis.

\section{b. Changes in ship design}

The generic term galleon is usually employed for the ships of the Manila trade and is very frequently found in AGI documents. The ships used in the trade during the sixteenth and seventeenth centuries correspond closely to the classic galleon design. These were vessels of three masts and two or three bridges; the latter rose high above the waterline and were the most salient characteristic of the type. The high bridges were designed to afford an advantage in small arms combat at close range, and to defend against boarding. Spanish galleons were traditionally built according to the "rule of 1-2-3," which meant that the length of the keel was to be three times the beam, and the beam twice the depth of the hold measured from the rear deck. Serrano Mangas (1985) discusses design data from a galleon built in the late seventeenth century; it displaced 1000 metric tons, and was $39 \mathrm{~m}$ long, with a beam of $11 \mathrm{~m}$, and a depth of $5 \mathrm{~m}$. Similar figures are given by Schurz (1939, chapter 5) for ships spanning a wide range of tonnage.

During the latter part of the seventeenth century, the design of ships in use by European navies became increasingly frigatelike. The height of the bridges was 
reduced and the length of the keel became greater in proportion to the beam and draft until, by the late eighteenth century, the ships had fully evolved into frigates. These changes came much more slowly to the merchant ships of the Manila trade, partly because of the colony's isolation from Europe and, perhaps more importantly, because the voyage put a premium on durability and cargo volume, qualities in which the galleons excelled. References to "frigates" in the AGI records do not become frequent until after 1750, and Schurz (1939) notes that the Santísima Trinidad, captured by Admiral Cavendish in 1762, was $156 \mathrm{ft}$ long at the keel, with a beam of $56 \mathrm{ft}$ and a depth of hold of $26 \mathrm{ft}$. These figures do not differ much from the 12-3 rule in use since the early seventeenth century. Nevertheless, we have adopted 1750 as the "transition date" for the design of the typical Manila ship, and have not used in the analysis any of the voyages from the last half of the eighteenth century. (It will be recalled that voyages after 1770 have already been rejected on the basis of changes in departure date, so the current restriction removes from consideration an additional 20 years). In all, considerations relating to ship design and starting date of the trip reduce the 141 references found acceptable earlier to 121, as shown in the last row of Table 5.

Even though the design of ships used in the Acapulco-Manila voyage remained fairly uniform through the seventeenth and first half of the eighteenth centuries, it is known that their size varied greatly even during this period. Attempts by the Crown to regulate the trade set a limit of 300 tons for the ships [from 1593 through 1718, when the limit was raised to 560 tons; Santiago Cruz (1962)]. The aim was apparently to limit the amount of Asian merchandise, particularly silks, that competed with similar products from Seville, and to restrict the large outflow of Mexican and South American silver. However, these regulations were essentially disregarded: Schurz (1939) cites galleons of 700 tons in 1589, 1000 tons in 1614, and 612,900 , and 1000 tons in 1718. The Rosario, which sailed between 1746 and 1761, was 1710 tons, and the famous Santísima Trinidad (1762) was 2000 tons, one of the largest ships afloat at the time. Evidently, the desire to maximize the tonnage of very profitable merchandise outweighed any sense of obligation to follow the edicts of the distant royal bureaucracy.

The large range of sizes of the Manila galleons does not translate into a similar range of speed. In our review of the AGI sources we found that speed is very rarely mentioned in connection with the Manila galleons; as we have seen, the ability to carry large amounts of cargo and withstand the rigors of the voyage were the principal desiderata. In fact, according to our data, the duration of the Acapulco-Manila voyage in the eighteenth century was, if anything, somewhat longer than at the end of the sixteenth century. Thus, it does not appear that inherent ship speed changed markedly during the period under consideration.

\section{c. Cargo and route}

Variations in the type and weight of cargo carried by the ships, as well as changes in the route followed, are two other factors that could have influenced the duration of the passage. We know precisely the type of cargo carried, and we know that it did not change significantly in the 250 years of operation of the line. The Manila-bound ships carried mainly silver: private consignments to pay for Asian goods, and the Crown subsidy to support the administration of the colony. Schurz (1939) comments that on the trip to Manila the ships sailed "virtually under ballast," but the amount of silver shipped is not known for most years. Presumably, this precious ballast would have been complemented by more usual materials - stones-if the weight of the silver had been insufficient to trim the ship properly. In the absence of any indication to the contrary, it is reasonable to assume that the nature and size of the cargo does not introduce any systematic error or spurious trend in the series of voyage duration.

Changes in the route to Manila could also introduce biases in the duration of the voyages, but here again all the available information indicates that the route changed very little throughout the life of the line. A typical Acapulco to Manila voyage was described in section 2; it was usually a safe and pleasant one, and relatively fast for its time. The ships sailed with the trade winds within the latitude range $10^{\circ}-15^{\circ} \mathrm{N}$. The voyages were purely commercial, the route west being strictly prescribed up to the Embocadero. This, and the steadiness of the trade wind system in the central Pacific during the months of the passage (AprJun), probably account for the fact that the Hawaiian archipelago $\left(24^{\circ} \mathrm{N}, 167^{\circ} \mathrm{W}\right)$ was not discovered by any of the ships of the Manila trade. Guam, on the other hand, was discovered by Magellan in 1521 and visited occasionally until the middle of the seventeenth century, when it became a regular stop in the Acapulco-Manila voyage. The galleons called at Guam to deliver mail and to replenish water supplies, if needed; however, stops were brief-one or two 
days - so they do not introduce a significant bias in the duration of the voyage.

In summary, of the more obvious factors that may contribute a spurious component to the voyage duration series, only the starting date and changes in ship design after 1750 appear to be significant. Since variations in starting date are not a problem before 1770 , limiting the time series to be analyzed to the period 1590-1750 eliminates both sources of error.

\section{Results}

The series of duration of the Acapulco-Embocadero trip is shown in Fig. 4. It is based upon the 121 voyages selected according to the criteria discussed above. The solid and dashed curves in the figure denote the 30-yr running mean, and the running mean \pm 1 standard deviation, respectively. The data show a large secular trend in voyage duration superimposed upon higher-frequency interannual variability. The trend is such that voyages are shortest in the late sixteenth and early seventeenth centuries, but become progressively longer from 1620 to 1660; after 1660, voyage duration again decreases, becoming more or less constant with time between 1700 and the end of the series in 1750 .

The trend in voyage duration stands out clearly above the large year-to-year variability. In particular, voyages during the 30 -yr period $1640-1670$ were very slow. If we compare this period with the 30 years at the beginning of the record, 1590-1620, the respective means and standard deviations are $122.7 \pm 27.8$ days and $79.0 \pm 16$ days. Application of the Student's

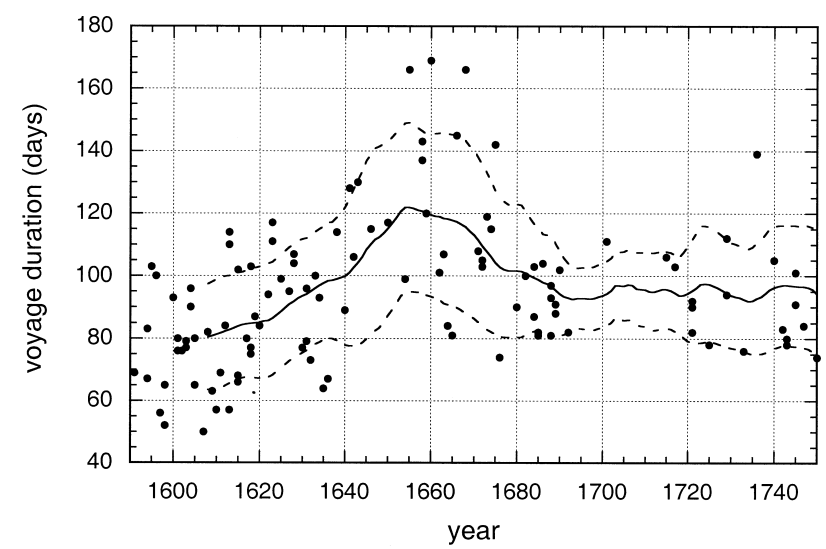

FIG. 4. The time series of voyage duration, 1591-1750. The $30-y r$ running mean is denoted by the solid line; the dashed lines indicates the mean \pm 1 standard deviation. t-test to these values shows the two means to be significantly different, with probability $p>99.99 \%$. A similar result is obtained when comparing 1640-1670 with the 30-yr period at the end of the record, 17201750. There are no apparent "societal" or "technological" explanations for these large changes in transit time to Manila. The more obvious sources of spurious variability have been discussed above and found to be unimportant, at least during the period under consideration, 1590-1750. On the other hand, additional documentary evidence from the AGI supports the finding that voyages became considerably longer in the midseventeenth century. Thus, in the years 1638-1671 we find 10 accounts of ships being lost or nearly lost in the vicinity of the Embocadero. Table 6 provides a list of these references; such reports occur throughout the period analyzed, but they are especially frequent in the years around 1650.

All of the ships listed in the table ran into trouble near the Embocadero. Examination of the original sources reveals that the ships encountered unfavorable winds and heavy seas, which caused them to run aground or to seek shelter in some port near the Embocadero. For example, the San Francisco Xavier was lost in 1655 during a heavy storm while anchored outside Borongo, on the east coast of Samar Island (AGI, Mexico 38, N42). A similar fate befell the San Nicolás de Tolentino, which ran aground and was wrecked near the same location 35 years earlier. The San José had a close call in 1660 when it was blown off course "to the gulf of Naga, in the province of Camarines, being saved by a miracle" (AGI, Filipinas 23, R2, N4). In 1663, the same ship encountered a storm "that lasted 40 hours, in which it lost all of its masts" (AGI, Filipinas 68). The Nuestra Señora de la Concepción arrived at the Philippines in June of 1666, but had to put in at Palapa to await favorable winds. In August of the same year it was still in that port, "whence it cannot sail and it is not known when it will be able to come [to Manila] for lack of [favorable] weather" (AGI, Contaduría 1237).

A more explicit reference to unusually difficult conditions comes from a letter to the Spanish king, written sometime after 1656 by an unknown correspondent, possibly a Crown officer (AGI, Filipinas 935):

H. M. has also ordered that the ships not wait until April [to sail from Acapulco]; this time was formerly held to be safe, but because of the changes in the monsoons and the great 
lengthening of the voyages it seems appropriate that navigation should commence earlier. ... It is considered a good voyage from the Philippines to Acapulco one that does not exceed 7 months, so in order to be able to return in time they should not wait until July to leave [Manila], but should move up the departure to early May. I traveled from Cavite in 1648 and the voyage took 7 months and 8 days, and in the year 1656, I departed at the end of July and took 7 and a half months. ... ${ }^{6}$

The correspondence makes reference to both the Manila-Acapulco and the Acapulco-Manila voyages, linking the success of the latter with an early departure in the former. (It should be remembered that the Acapulco-Manila voyage was actually the return trip since the annual voyages were organized by the merchants of Manila and were viewed as originating from that port.) The writer notes that it is no longer safe to leave Acapulco any time in April because unfavorable winds will likely be found near the Philippines. Further, if the ship is to sail earlier from Acapulco, it must also leave earlier from Manila_in May, rather than the customary July-because the eastward trip is also taking an unusually long time. A seven-month voyage departing Manila in mid-July would arrive in Acapulco in mid-February, scarcely in time for the Acapulco fair; several weeks were required thereafter to repair and reprovision the ship for the return trip to Manila. Thus, a ship arriving in mid-February would be hard pressed to return before the end of March. All of this suggests that whatever was causing the Acapulco-Manila voyage to become longer also affected the passage from Manila to Acapulco. This issue is discussed further in section 7 .

\section{Interpretation}

To gain insight into the nature of the circulation changes that could have caused the very large trend in voyage duration seen in Fig. 4, we have used wind data for 1948-99 to construct "virtual voyages" of the

\footnotetext{
${ }^{6}$ Other manuscript sources confirm the account of extremely long eastward voyages given in this letter. In 1648, the Nuestra Señora de la Encarnación left Manila on 7 May and arrived in Acapulco on 12 December, a journey of 219 days (AGI, Contaduría 905B, Filipinas 31). In 1656, the San José took 228 days to make the trip (30 July to 15 Mar 1657; AGI, Contaduría 905B).
}

Manila galleon. These virtual voyages were produced by "sailing" a hypothetical galleon between Acapulco and Manila at a speed determined by the actual winds observed on each of the years in the modern dataset. The winds were obtained from the National Centers for Environmental Prediction (NCEP) reanalyzed dataset. Reanalyzed surface wind data are available on a $2.5^{\circ} \times 2.5^{\circ}$ grid; these data are identified as "class A," that is, they are influenced most strongly by actual observations and are least dependent on model parameterizations. Descriptions of the NCEP reanalysis project can be found in Kalnay et al. (1996) and Kistler et al. (2001).

\section{a. The virtual voyages}

To construct the virtual voyages, we used NCEP vector winds for the period 1948-99 to determine the travel time of a ship sailing from Acapulco on 30 March, proceeding southwest to $12^{\circ} 30^{\prime} \mathrm{N}$; then west to the Embocadero. (The procedure used to determine a "transfer function" between the speed of the ship and the vector wind is described in the appendix.) We chose the Embocadero rather than Manila as the terminus for the virtual voyages because of the difficulty of estimating the course and ship speed within the inland waters of the Philippine archipelago. As seen in Fig. 2, the navigation between the Embocadero and Manila involved a tortuous route among many islands, making it impossible to deduce local winds from the NCEP data, whose spatial resolution is $2.5^{\circ}$. Furthermore, currents in the several straits that had to be traversed are often strong and likely affected the ship's progress to a degree dependent on the circumstances of each trip. On the other hand, the voyage of the Embocadero took place in the open ocean with minimal deviations from the standard route, so use of the NCEP data for reconstructing this part of the trip is much more easily justified. In addition, surface currents near $12^{\circ} 30^{\prime} \mathrm{N}$, the nominal latitude of the Pacific crossing, are relatively weak, since this latitude lies between the cores of the (easterly) north equatorial current $\left(\sim 15^{\circ} \mathrm{N}\right)$ and the (westerly) equatorial countercurrent $\left(\sim 5^{\circ} \mathrm{N}\right)$; the mean zonal currents at $12^{\circ} 30^{\prime} \mathrm{N}$ during April-June are easterly, and of the order of $10 \mathrm{~cm} \mathrm{~s}^{-1}$ (Meehl 1982). Since ship speed across the Pacific was about $2 \mathrm{~m} \mathrm{~s}^{-1}$, to a first approximation the effects of currents can be disregarded in the computation of travel time to the Embocadero.

The mean duration of the Acapulco-Embocadero trips computed from NCEP data (without any adjustment to the ship speed vs wind relationship) was 82.5 
days, compared to 92.48 days for the mean of the historical data (1590-1750) shown in Fig. 4. Thus, a "normalization factor" of 0.89 was introduced in the transfer function to make the mean NCEP voyage duration equal to the mean for the historical data. The fact that, even without this adjustment, the mean durations of the virtual and historical voyages are in quite good agreement increases our confidence in the validity of the transfer function described in the appendix.

We then proceeded to recompute travel times to the Embocadero for each year of the NCEP dataset using the adjusted transfer function; the results are shown in Fig. 5. The standard deviation of the duration of the virtual voyages is $\sigma=9.8$ days, less than half as large as that found for the historical data in Fig. 4. However, the results shown in Fig. 5 include only variability due to interannual changes in the wind because all the virtual voyages originate on the same date (30 Mar). An estimate of the standard deviation due to differences in starting date can be made by constructing an additional set of virtual voyages wherein the wind field is kept constant, but the starting date is varied according to the distribution of historical starting dates. This procedure yields a standard deviation of $\sigma^{\prime}=7.03$ days attributable to changes in starting day alone. Assuming that this is independent from the variability due to changes in the wind, then the total standard deviation of virtual voyage duration

TABLE 6. Ship losses and near losses (*) in the Acapulco-Manila trip, 1590-1750.

\begin{tabular}{|c|c|c|c|}
\hline Year & Ship & Location & References \\
\hline 1591 & San Ildefonso & Unknown & Mexico 22, N11, and N46 \\
\hline 1601 & Santo Tomás & Cabo Espíritu Santo ${ }^{a}$ & Mexico 25, N4; Patronato 263, N1, R7, and R8 \\
\hline 1620 & $\begin{array}{l}\text { San Nicolás de } \\
\text { Tolentino }\end{array}$ & Borongán ${ }^{\mathrm{a}}$ & Contaduría 904, Filipinas 7, R5, N61 \\
\hline 1639 & San Ambrosio & Cagayán ${ }^{\mathrm{a}}$ & Contaduría 1220 \\
\hline 1646 & San Luis & Cagayán & Filipinas 31 \\
\hline 1649 & $\begin{array}{l}\text { Nuestra Señora de } \\
\text { la Encarnación }\end{array}$ & $\begin{array}{l}\text { "near the } \\
\text { Embocadero" }\end{array}$ & $\begin{array}{l}\text { Contaduría 901B; Filipinas 9, R1, N13; } \\
\text { Filipinas } 31\end{array}$ \\
\hline 1654 & San Diego & Lyam, or Luyama & Filipinas 31 \\
\hline 1655 & $\begin{array}{l}\text { San Francisco } \\
\text { Xavier }\end{array}$ & Borongo (Borongán) & Filipinas 28; Filipinas 30; Mexico 38, N42 \\
\hline $1660^{*}$ & San José & Punta Naga ${ }^{\mathrm{a}}$ & Filipinas $23, \mathrm{R} 2, \mathrm{~N} 4$ \\
\hline $1663^{*}$ & San José & Cagayán & $\begin{array}{l}\text { Filipinas 9, R3, N40; } \\
\text { Filipinas 28; Filipinas } 68\end{array}$ \\
\hline $1666^{*}$ & $\begin{array}{l}\text { Nuestra Señora de } \\
\text { la Concepción }\end{array}$ & Palapa $^{\mathrm{a}}$ & Contaduría 1237; Filipinas 9, R3, N49 \\
\hline $1671^{*}$ & $\begin{array}{l}\text { Nuestra Señora } \\
\text { del Buen Socorro }\end{array}$ & Palapa & Mexico 47, R2, N22 \\
\hline 1730 & Sacra Familia & Mindoro $^{\mathrm{a}}$ & Filipinas 148 \\
\hline 1735 & San Cristóbal & Embocadero & Escribanía 477 \\
\hline
\end{tabular}

${ }^{a}$ See Fig. 2 for locations of geographical points. 
would be $\sigma_{T}=\left(\sigma^{2}+\sigma^{\prime 2}\right)^{1 / 2}=12.06$ days. This is still considerably smaller than the standard deviation of the historical data, which suggests that the latter contains additional variance due to inaccuracy of the historical sources, and perhaps also to greater natural variability in the winds during the historical period. Figure 5 also shows that many of the fastest virtual trips take place in the late 1940s and the decade of the 1950s, while slow trips are more common thereafter. This behavior is reminiscent of the secular trend in voyage duration seen in Fig. 4, but the trend is much smaller for the virtual voyages.

Further examination of the virtual trips yields some interesting results. Figure 6 shows the longitude as a function of time for the 9 fastest and slowest trips, and for the average of all 52 trips (1948-99). The mean durations for the sets of fastest and slowest trips are 80.0 and 108.2 days, respectively, a difference of 28.2 days. The average trip (thick dotted line) indicates three regimes of "ship speed." Immediately upon leaving Acapulco, as the ship travels SW to $12^{\circ} 30^{\prime} \mathrm{N}$, it moves relatively slowly in longitude; near $110^{\circ} \mathrm{W}$, it picks up speed as it begins to move westward with the trade winds. Ship speed is fairly uniform across the Pacific up to about the longitude of Guam $\left(144^{\circ} 47^{\prime} \mathrm{E}\right)$, where the rate of westward progress decreases again. Except for three voyages with very slow starts $(1997,1986,1974)$, slow voyages are only marginally slower than fast ones over the first half of the Pacific crossing, but beyond the date line they fall behind more rapidly. Figure 7 shows that, as a group, slow voyages arrive at Guam about 15 days later than fast voyages, and they lose an additional 13 days be-

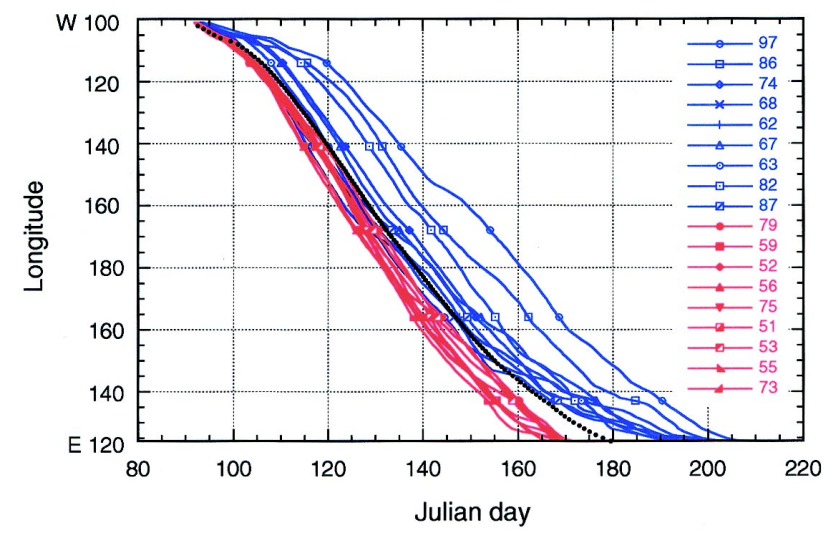

FIG. 6. Position (longitude) vs time for the nine slowest (red) and nine fastest (blue) voyages constructed from NCEP data. The average for all 52 voyages between 1948 and 1999 is shown in black.

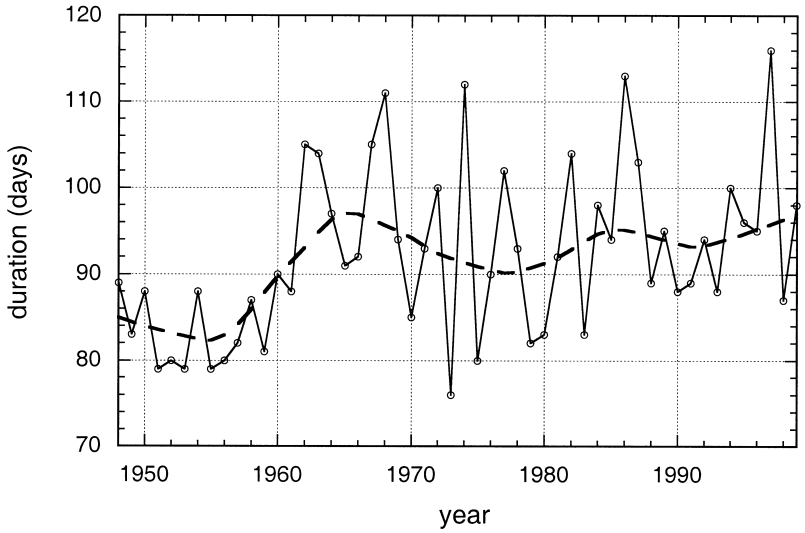

FIG. 5. Duration of the Acapulco-Embocadero voyage calculated using NCEP winds for 1948-99. The dashed line is a smoothed version of the data.

tween Guam and the Embocadero. All of this points to conditions in the western Pacific as the most important determinant of voyage duration in the modern data.

\section{b. The seasonal cycle in the tropical western Pacific}

To place the foregoing results in context, we show in Fig. 8 the surface wind field in the western Pacific during the months of June and July from the Comprehensive Ocean-Atmosphere Data Set (COADS) observations for 1900-1979 (Woodruff et al. 1987; Sadler et al. 1987). This period covers a large part of the Acapulco-Philippines voyage west of the date line, as can be ascertained from Fig. 6. The salient feature of the surface streamlines is the western Pacific mon-

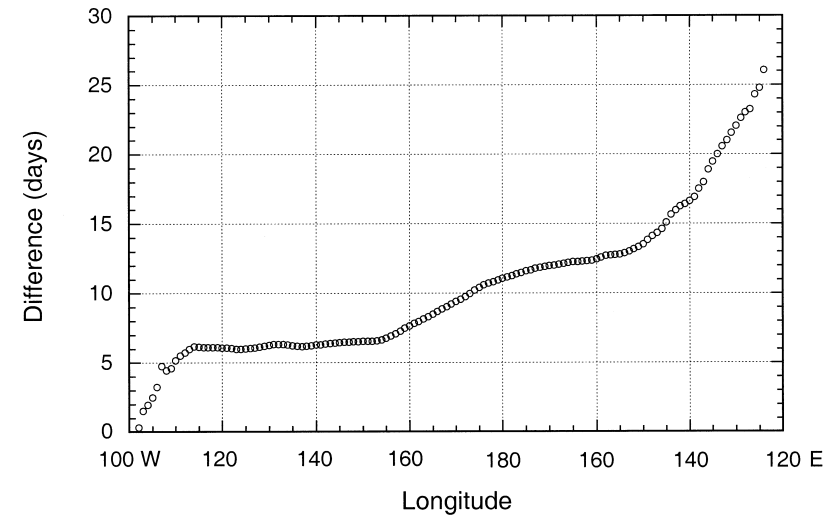

FIG. 7. Difference in the date at which given longitudes are reached for the nine slowest and nine fastest voyages constructed from NCEP data. All voyages start from Acapulco $\left(100^{\circ} \mathrm{W}\right)$ on 30 Mar. Guam and the Embocadero are located at approximately $144^{\circ}$ and $124^{\circ} \mathrm{E}$, respectively. 

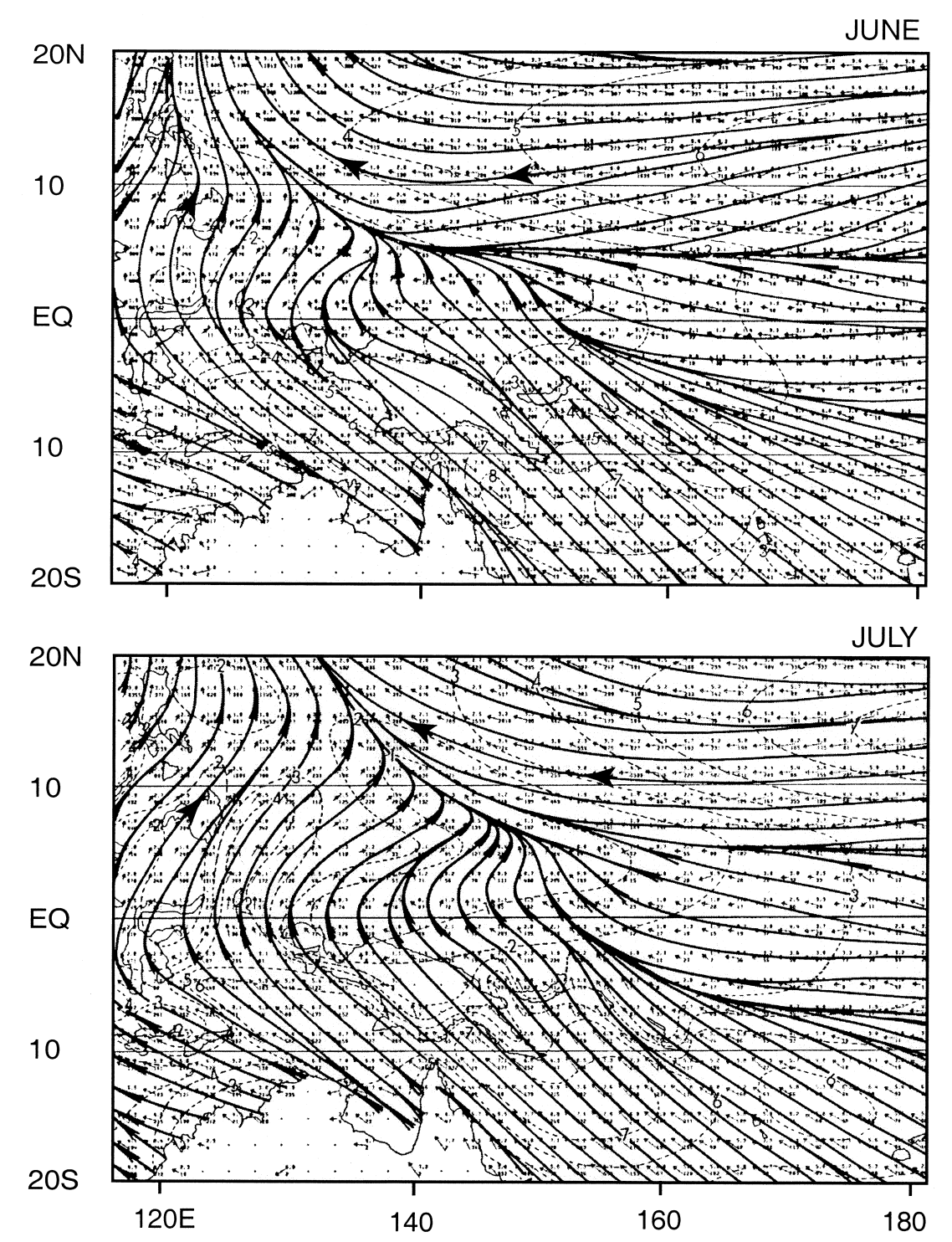

Fig. 8. Climatological streamlines of the surface wind in the western tropical $\mathrm{Pa}$ cific during Jun and Jul. Adapted from Sadler et al. (1987).

tions would be even more favorable, since at that time the trade wind circulation extends all the way to the Philippines. In late June or July, on the other hand, a ship would have to contend with southwest winds throughout most of the Guam-Embocadero leg.

Changes in the precipitation regime of the tropical western $\mathrm{Pa}$ cific accompany the movement of the monsoon trough. Examination of NCEP precipitation data for June and July (not shown) indicates that precipitation west of Guam follows the movement of the monsoon trough, such that in June the heaviest precipitation occurs south of $12^{\circ} 30^{\prime} \mathrm{N}$, but in July the region of heavy precipitation encroaches upon the route followed by the ships. This implies that, in addition to unfavorable winds, a ship sailing between Guam and the Philippines in late June or July would also have faced heavy weather associated with tropical convective systems. Insofar as such weather may have impeded further the progress of the ship, the differences in travel time between the slow and fast virtual voyages of Fig. 6 may be underestimated. This may account for the fact that the difference between the nine fastest and nine slowest virtual voyages (28.2 days)

soon trough, the region of convergent flow that extends from the South China Sea to the vicinity of the Philippines, and eastward toward Guam $\left(13^{\circ} 28^{\prime} \mathrm{N}\right.$, $\left.144^{\circ} 47^{\prime} \mathrm{E}\right)$. The trade winds dominate the circulation east and north of the trough, where they merge with southerly and southwesterly flow originating south of the equator. In June, the monsoon trough is located midway between Guam and the Philippines, but in July it moves eastward, passing very close to the location of Guam. Thus, a ship sailing between Guam and the Embocadero in June would encounter easterly winds to near $130^{\circ} \mathrm{W}$, and southerly winds west of this longitude, as it passed the zone of convergence between the trades and the monsoon flow. If the ship reached Guam in late May or early June, the condi- is considerably smaller than the difference between the fastest and slowest historical voyages shown in Fig. 4.

\section{c. Circulation differences between fast and slow trips}

The wind field in the tropical Pacific provides a clear picture of how the differences between the fast and slow voyages develop. Figure 9 shows the June vector wind field composited for the sets of fast and slow years. There is a striking difference in the strength of the trade winds and the position of the monsoon trough in the two sets of years. In the fast years, trade winds west of the date line are stronger; more importantly, they extend considerably farther westward, so the monsoon trough is displaced west 
and south with respect to the slow years. Under the conditions prevailing in the fast voyage years it would be possible to sail almost all the way to the Philippines with the trade winds. On the other hand, in the years when the voyages are slow, a ship would have encountered the monsoon trough halfway between the date line and the Philippines, at about the longitude of Guam. These circulation differences account for the delays experienced in the slow trips west of the date line, and especially west of Guam. Further delays occur near the Philippines, since the slowest voyages traverse the range of longitudes between $130^{\circ} \mathrm{W}$ and the Embocadero in July, a time when both unfavorable winds and vigorous convection predominate.

It was noted in connection with Fig. 5 that many of the fast virtual voyages take place in the $1940 \mathrm{~s}$ and 1950s. In fact, the June vector wind field composited over the period 1948-60 (not shown) is very similar to the composite for the fast voyage years (top panel in Fig. 9). The result is not surprising since six of the nine years that make up the composite of fast voyages belong to the decade of the 1950s (1951-53, 1955, 1956, and 1959). Nevertheless, all of the fast voyage years as well as a majority of the years prior to 1961 have a basic feature in common: the monsoon trough is displaced southward and westward. In the years after 1961, the wind field is rather more variable, and slow voyages are much more frequent in this period than before 1961. All the slow voyage years are characterized by northward and eastward displacement of the monsoon trough.

The clustering of fast voyages in the late 1940s and 1950s raises the question whether this is due to

\section{Fast Voyages}

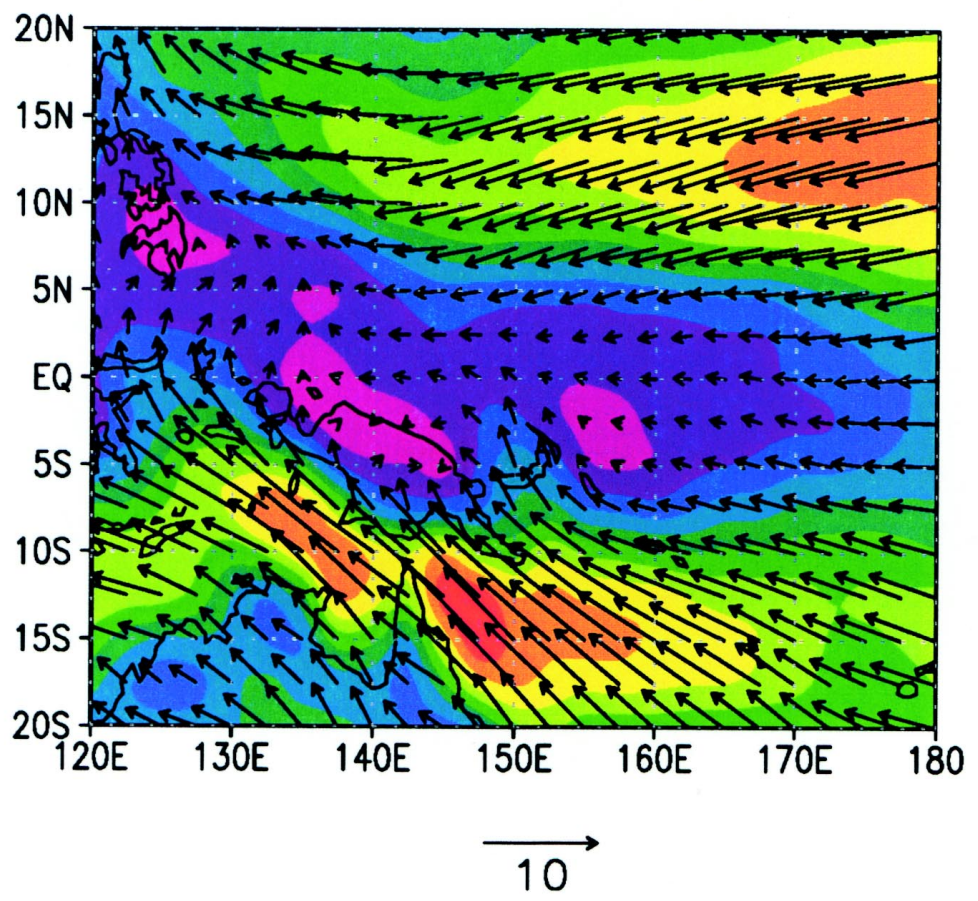

Slow Voyages

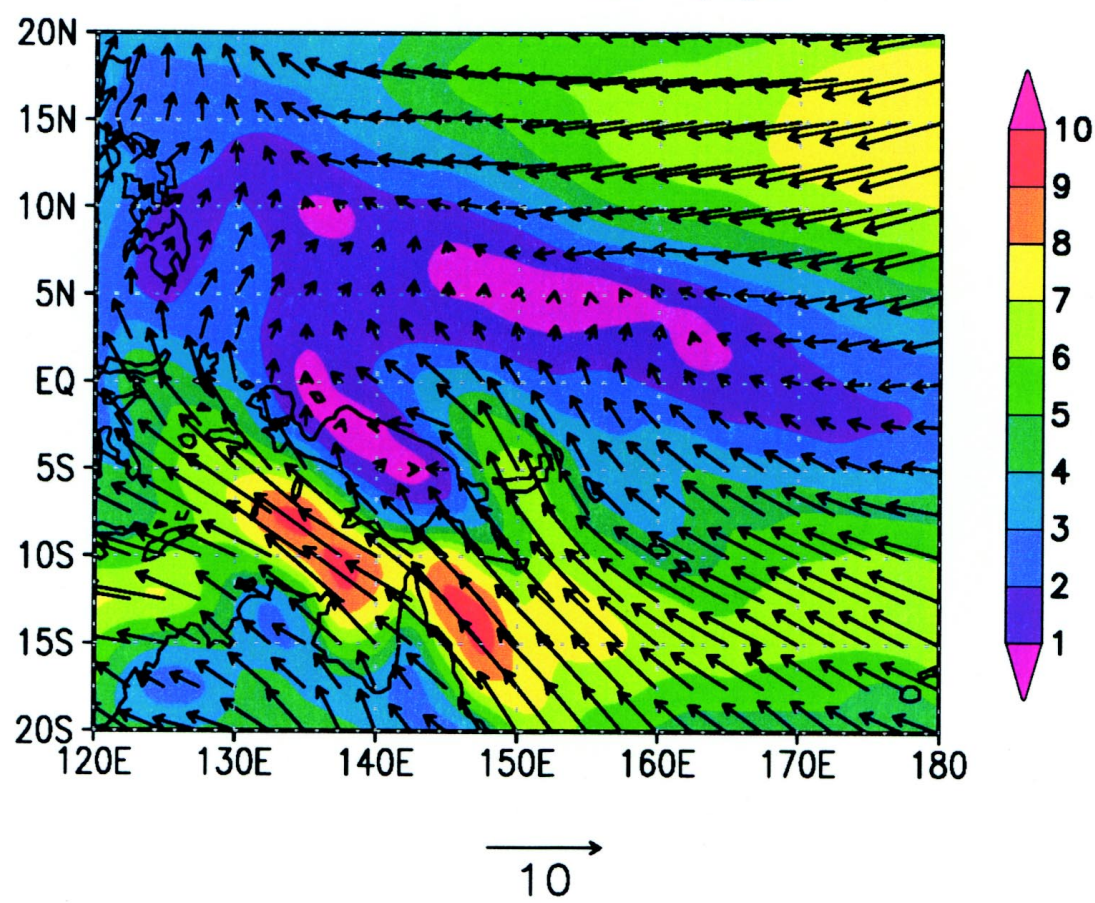

FIG. 9. Mean Jun vector wind field $\left(\mathrm{m} \mathrm{s}^{-1}\right)$ for the ensembles of nine fastest and nine slowest virtual voyages. Arrows indicate the vector wind and colors the wind magnitude $\left(\mathrm{m} \mathrm{s}^{-1}\right)$. NCEP reanalysis data provided by the NOAA-CIRES Climate Diagnostics Center, Boulder, CO. 
an actual change in the climatology of the monsoon or whether the early NCEP data could contain systematic errors. The NCEP reanalyses before about 1968 are more strongly influenced by observations from COADS than in later years, and it is possible that these data may be biased toward stronger easterly winds in the western Pacific. Two findings argue against this possibility: In the first place, we have seen that what happens in the western Pacific during fast voyage years is not just a change in the strength of the trade winds but a shift in the position of the monsoon trough (which allows the trades to extend nearly to the Philippines in Jun). While biases in wind magnitude could easily arise from changes in the method of observation, it is much less likely that such changes would lead to a bias in wind direction. In addition, we have derived a zonal wind speed index using surface pressure data for the western Pacific (Kaplan et al. 2000) in order to have a second, independent measure of the strength of the trades. This index (not shown) behaves very much like the NCEP zonal winds, such that when the meridional surface pressure gradient is large, easterly winds are strong, and vice versa; the correlation coefficient between the two time series is -0.81 . Thus, it appears likely that the clustering of fast voyages before 1962 is due to an actual difference in the climatology of the western Pacific monsoon in those years compared to the later years of the modern record.

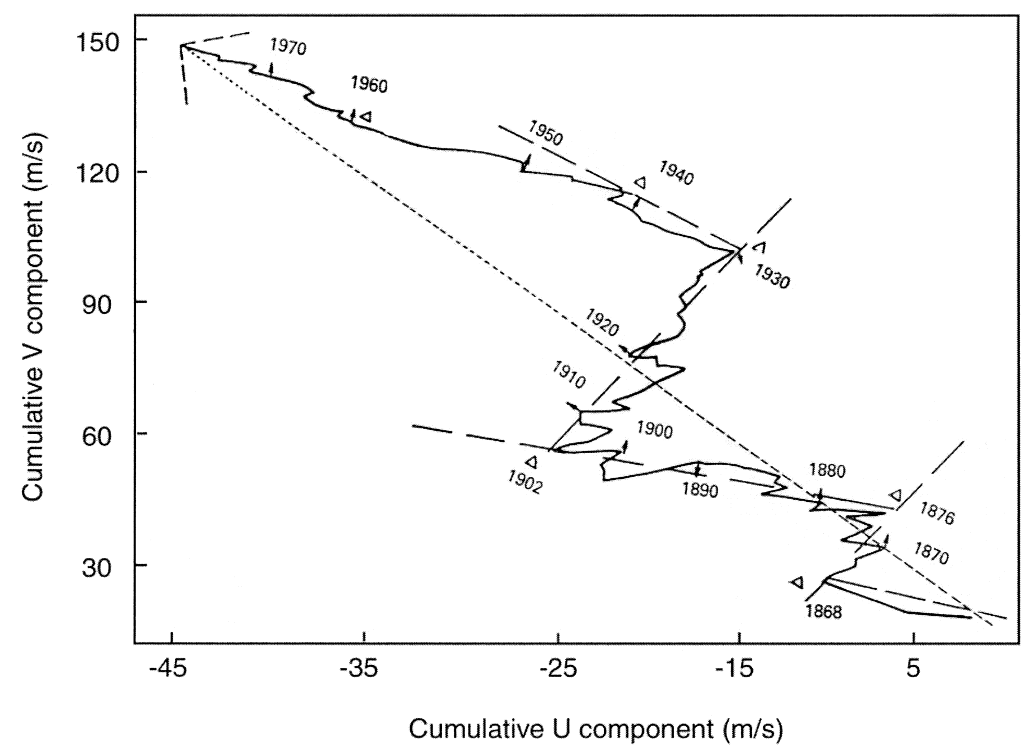

FIG. 10. Cumulative wind vector for the region $0^{\circ}-20^{\circ} \mathrm{N}, 120^{\circ}-160^{\circ} \mathrm{E}$. The points labeled along the vector trajectory indicate years in the record. The vector shown, which joins the origin and end points of the trajectory, is the cumulative vector wind for 1860-1980. Adapted from Fu and Fletcher (1988).
The foregoing results may be summarized by noting that the duration of the virtual voyages is strongly dependent on the circulation in the western Pacific, that is, on the strength of the trade winds west of the date line and the position of the monsoon trough during June. Furthermore, years of fast and slow voyages tend to occur in clusters over at least part of the period covered by the NCEP data. All of this suggests that the secular trends observed in the duration of the historical voyages can be interpreted in terms of decadal changes in the atmospheric circulation of the western Pacific Ocean. If this interpretation is correct, then the early years of the seventeenth century would have been characterized by the circulation similar to that shown in the top panel of Fig. 9, while a circulation more like that of the bottom panel of the figure would have prevailed in the middle years of the century.

\section{Discussion}

We have argued that secular variations in the length of the Acapulco-Manila voyages during the period 1590-1750 are unlikely to have been caused by changes in ship design, route, cargo, or other societal or technological factors; on the other hand, we have shown that the duration of "virtual voyages" constructed from modern (NCEP) wind data depends critically on the circulation over the western Pacific. Our series of virtual voyages does not exhibit differences between slow and fast trips as large as those found in the historical data (over 40 days on average between the beginning and the middle of the seventeenth century); nor does it contain decadal-scale trends comparable to those present in the historical series (fast voyages between 1590 and 1630, much slower voyages between 1640 and 1670, and faster voyages again toward the end of the century). However, there is evidence of changes in the western Pacific during the last century that surpass in magnitude and persistence those found in the period covered by the NCEP dataset.

Fu and Fletcher (1988) have analyzed the variability of the circulation in the entire Asian monsoon region (Arabian Sea, Bay of Bengal, South China Sea, and western Pacific). Figure 10, adapted from their work, shows the cumulative 
wind vector in what they call the tropical convergence zone $\left(0^{\circ}-20^{\circ} \mathrm{N}, 120^{\circ}-160^{\circ} \mathrm{E}\right)$, which coincides broadly with the location of the western Pacific monsoon trough. The figure is constructed using summertime-mean (Jun-Aug) COADS observations for the period 1860-1980; because COADS observations are sparse before 1891, the results for the years 1860-90 must be interpreted with caution. Nevertheless, several interesting features are immediately apparent in the figure, the most striking being the large and persistent shifts in the direction of the wind over the period of record. Fu and Fletcher ascribe this behavior to shifts in the position of the monsoon trough, in agreement with our interpretation of the NCEP data. Such changes can take place on timescales ranging from annual to decadal. For example, while the cumulative wind for the entire period 1860-1980 blows approximately from the SSE, during the 28-yr interval 1902-30 the wind originates in the SSW. Note also that the year-to-year variability during the interval 1940-60 is remarkably low, consistent with the small fluctuation in the duration of our virtual voyages during the late 1940s and 1950s (see Fig. 5).

The decadal-scale variability can be appreciated more clearly in Fig. 11, which is a simplified version of Fig. 10. The figure displays multiyear intervals when the wind is directed predominantly along a certain direction, but omits the short-term variability present in Fig. 10. In addition, both axes of Fig. 11 are drawn to the same scale so that wind direction can be determined from inspection. Thus, the cumulative vector wind for the entire period of record (18601980) blows from $19^{\circ} \mathrm{E}$ of south, as indicated in the figure. For the years 1940-60, an interval that includes our fast virtual voyages of the late 1940s and 1950s, the wind direction is $41^{\circ} \mathrm{E}$ of south, considerably more easterly than the long-term wind vector, and consistent with the position of the monsoon trough shown in the top panel of Fig. 9. On the other hand, the cumulative vector for 1960-80, when many of our slow virtual voyages take place, is in much closer alignment with the long-term wind. The change in wind regime between the intervals $1940-60$ and $1960-80$ is by no means the largest seen in the record. As noted above, the surface winds for the 29-yr period 1902-30 are predominantly from the SSW $\left(10^{\circ} \mathrm{W}\right.$ of south), and they have a strong southerly component; this period follows the 27-yr interval 1876-1902 when the wind was nearly southeasterly $\left(50^{\circ} \mathrm{E}\right.$ of south) and the southerly component was weaker. We have not attempted to calculate virtual voyage durations during

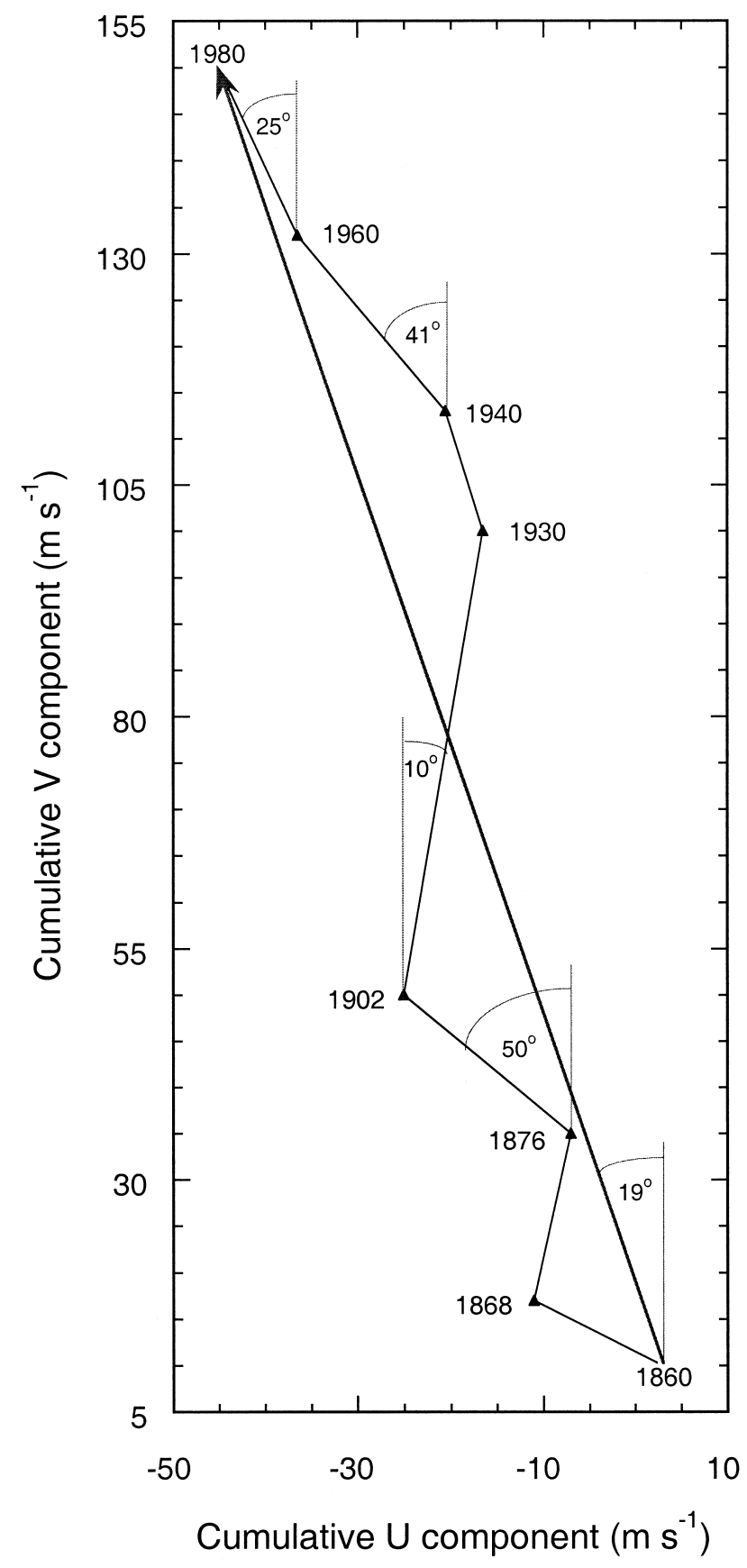

FIG. 11. A simplified version of the cumulative wind plot in Fig. 10. Both axes are drawn to the same scale so the direction of the vector wind can be appreciated directly from the figure. The cumulative vector wind for the period 1860-1980 is approximately SSE (19 ${ }^{\circ} \mathrm{E}$ of south). During the interval $1940-1960$ the wind blows from $25^{\circ} \mathrm{E}$ of south, while for $1960-80$, it is almost southeasterly $\left(41^{\circ} \mathrm{E}\right.$ of south).

these periods. However, it is likely that differences between 1876-1902 and 1902-30 would be considerably larger than those calculated for the 1948-99 interval covered by NCEP data (Fig. 5). 


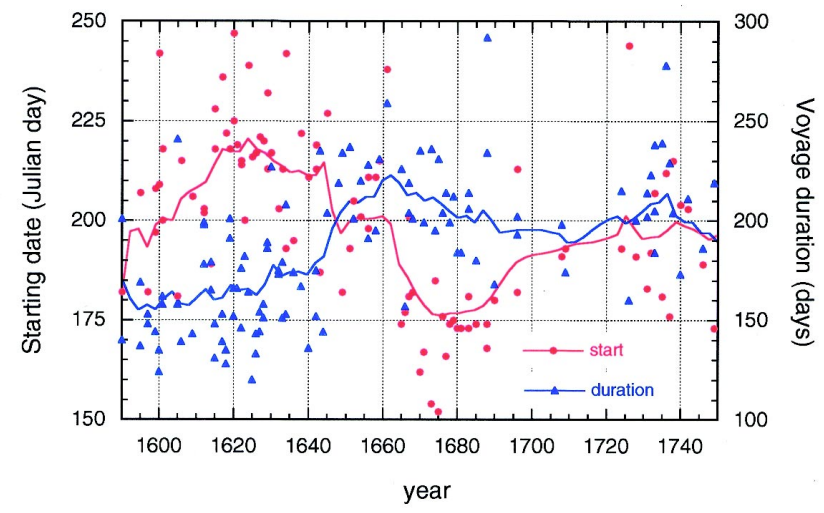

FIG. 12. Duration of the Manila-Acapulco voyage (blue triangles) and the starting date of the voyage (red dots). The continuous curves are smoothed versions of the data.

According to Fu and Fletcher (see their Fig. 11), large shifts in western Pacific winds are related to changes in the atmospheric circulation over the entire Asian monsoon region. They note that, when the monsoon in the Bay of Bengal has a strong southerly component, the monsoon trough in the western $\mathrm{Pa}$ cific is displaced west- and southward, while the opposite occurs when the winds in the Bay of Bengal are more southwesterly. Parthasarathy et al. (1991) have used Fu and Fletcher's results to argue that these circulation changes are accompanied by changes in monsoon rainfall over India. Similar conclusions have been reached by Kripalani and Kulkarni (1997), who show that monsoon rainfall over India and the northern Philippines are anticorrelated. The interpretation of these regional-scale relationships is the subject of ongoing research (Lau and Yang 1997), but the real-

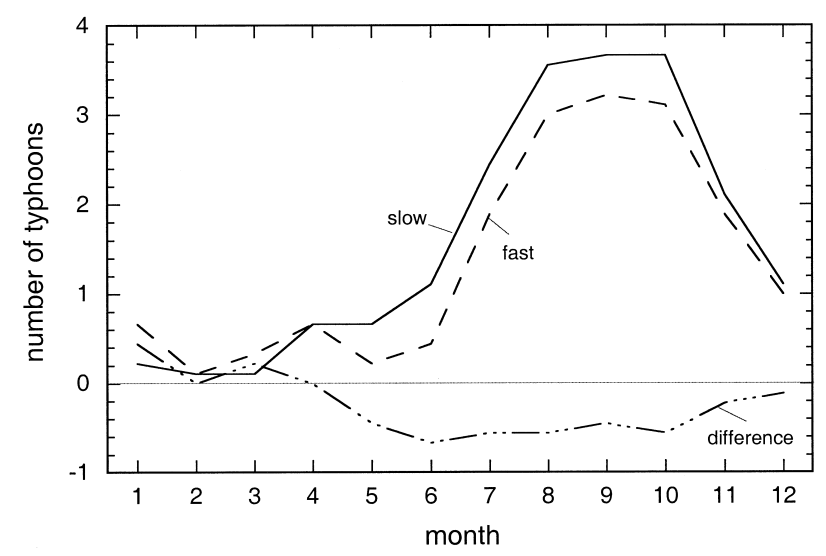

FIG. 13. Annual variation in the mean number of typhoons for the ensembles of fast and slow virtual years in Fig. 6. The difference between the number of typhoons in fast minus slow years is also shown. ity of large and prolonged shifts in the circulation over the western Pacific appears to be beyond doubt. In light of this finding, the duration and magnitude of the secular trend in voyage duration derived from historical data are quite plausible, and suggest that the seventeenth century was witness to major changes in the wind system of the western Pacific.

Analysis of the duration of the eastward voyage, from Manila to Acapulco, provides another indication that such changes did indeed take place. These data have not undergone a careful selection process like that described in section 3, so the results, shown in Fig. 12, must be considered preliminary. The figure displays both the duration of the voyage and the departure date from Manila over the period 1590-1750. The time series of duration of the eastward voyage resembles that of the westward voyage (Fig. 4) in that there is a rapid increase in duration after about 1630 (from about 160 to well over 200 days), and the longest voyages (230-240 days) occur around 1660-70. However, the duration of the Manila-Acapulco voyage does not decrease much in the latter part of the seventeenth century, but remains approximately constant at just under 200 days.

The behavior of the duration series is mirrored by the series of starting dates. The voyages begin in midto late July in the first half of the seventeenth century, but after 1660 there is a rather abrupt shift to earlier starting dates, in late June. It is tempting to interpret this change as a response to the increasing length of the eastward voyage. In fact, this interpretation is supported by the letter from the AGI collection quoted in section 5 . It will be recalled that this letter, written sometime after 1656, acknowledges the desirability of advancing the departure from Manila from July to May in view of the inordinate length of the eastward voyage. The exact nature of the circulation changes responsible for the increase in voyage duration seen in Fig. 12 is not known, and construction of virtual voyages from Manila to Acapulco is difficult because the route was by no means as well defined as on the westward journey. One possibility is that eastward voyages departing in July began to encounter an increasing number of tropical cyclones since, according to the AGI sources, these constituted the most frequent problem faced on the Manila to Acapulco voyage. Figure 13 shows the annual variation in the mean number of western Pacific typhoons (tropical cyclones with sustained winds $>33 \mathrm{~m} \mathrm{~s}^{-1}$ ) for the sets of fast and slow virtual voyage years. The number of storms is consistently smaller for the fast 
voyage years (about 20\% fewer storms during the peak activity months of Jul-Oct). Further study of this issue is clearly needed.

The evidence presented above suggests that profound changes in the atmospheric circulation of the western Pacific region took place during the seventeenth century, and that the magnitude of these changes was considerably larger than anything experienced during the last half of the twentieth century. Our findings also suggest that the relationship between the western Pacific monsoon trough and the largerscale circulations associated with the Indian and East Asian monsoons bears further detailed examination. This topic is by no means unexplored (see, e.g., Tao and Chen 1987), but much of the relevant literature is in Chinese and thus unavailable to most researchers working in the West. It is to be hoped that the ongoing South China Sea Monsoon Experiment (Lau et al. 2000) will foster the international cooperation necessary to elucidate this important aspect of the tropical circulation.

Acknowledgments. The authors wish to thank Mr. Cruz Apestegui for advice on the design and sailing characteristics of the Manila galleons, and Drs. A. K. Smith, W. Randel, P. Gent, and A. Kaplan for their comments on the original manuscript. Valuable comments were also provided by two anonymous reviewers. This work was supported in part by a Small Grant for Exploratory Research from the Earth System History (ESH) Program of the National Science Foundation (NSF); the support and encouragement of former ESH Director Dr. Howard Zimmerman is gratefully acknowledged. The National Center for Atmospheric Research is sponsored by NSF.

\section{Appendix: The relationship between ship speed and vector wind}

To estimate the progress of a galleon from modern wind data, it is necessary to develop a transfer function between the ship's speed along a given course and the vector wind. The forward speed of the ship depends on the balance between the force exerted by the wind upon the sails and the drag experienced by the hull as it moves through the water (see, e.g., Garrett 1996). The latter is proportional to the square of the ship's speed, $V_{s}$, while the former depends upon the square of the true wind speed, $V_{t}$, times a complicated function of $V_{t}$ and the angle, $\delta$, between the direction of the wind (in the frame of reference moving with the ship) and the direction of travel of the ship. Equating the two forces gives a relationship between $V_{s}$ and $V_{t}$ that can be written as

$$
\frac{V_{s}}{V_{t}}=\alpha f\left(V_{t}, \delta ; C\right),
$$

where $C$ is a parameter that depends on the hydrodynamic characteristics of the hull and the efficiency of the sails, and $\alpha$ is a "calibration factor" whose purpose is to adjust the mean Acapulco to Philippines travel time obtained using (A1) to the mean travel time derived from the historical data.

When $C$ is small (as would be the case for slow ships like the Manila galleons), $\delta$ becomes approximately equal to the true angle between the wind and the course of the ship and solution of (A1) is simplified somewhat. An analytical solution is not possible in general because $f(V, \delta ; C)$ involves trigonometric functions that make the equation transcendental, but an iterative numerical solution is fairly easily implemented. Figure A1 is a "polar diagram" illustrating the dependence of $V_{s} / V_{t}$ upon the angle $\delta$, which is measured from the direction of travel of the ship. (Thus, $\delta=0$ means that the wind is blowing in the same direction as the ship is traveling while $\delta=180^{\circ}$ signifies a head wind.)

As shown in Fig. A1, forward movement is not faster with a following wind $(\delta=0)$, but rather when the wind blows somewhat forward to the stern. This effect is slight for a slow ship $[C=0.1 \mathrm{in} \mathrm{Eq.} \mathrm{(A1)],}$

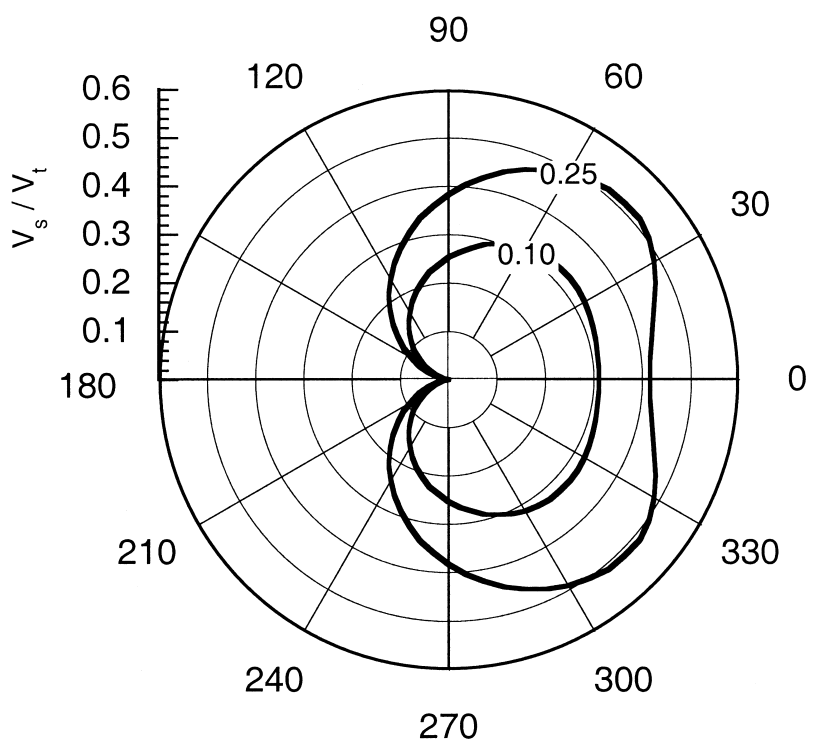

FIG. A1. Polar diagram of the function $V_{s} / V_{t}(\delta)$ relating forward ship speed, $V_{s}$, to true wind speed $V_{t}$, and angle of the wind with respect to the direction of travel of the ship $\delta$. The largest forward speeds are obtained when $30^{\circ}<\delta<60^{\circ}$. The curve marked $C=0.1$ refers to a slow ship; that marked $C=0.25$, to a somewhat faster ship. 


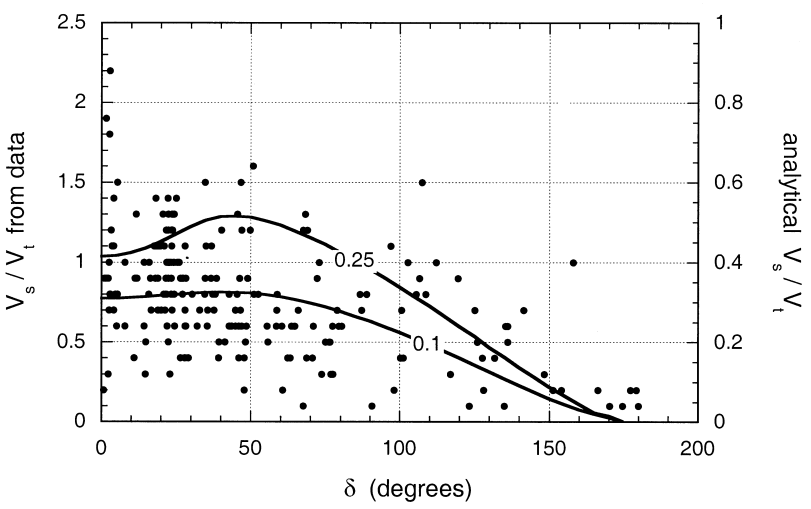

FIG. A2. The theoretical function $V_{s} / V_{t}(\delta)$ plotted in $x-y$ format for comparison with data extracted from the logbooks from four Manila galleons (La Soledad, 1767-68; San Pedro, 1779; El Príncipe, 1779-80; and Magallanes, 1808).

but becomes more marked for a faster $\operatorname{ship}(C=0.25)$. Figure A2 shows the function $V_{s} / V_{t}$ for the two values of $C$, together with data on ship speed and wind direction extracted from the logbooks of four AcapulcoManila voyages (AGI, Filipinas 975; AGI, Mexico 1369; AGI, Guadalajara 520; and Archivo del Museo Naval de Madrid, MSS 577). The scatter of the data is quite large, partly because the logbooks give wind speed on a qualitative scale that had to be assigned approximate numerical values. Nevertheless, the decrease in forward speed as the wind begins to blow forward of the ship's beam $\left(\delta>90^{\circ}\right)$ is evident. It is also apparent that (A1) with $C=0.1$ is a better fit to the data than with $C=0.25$.

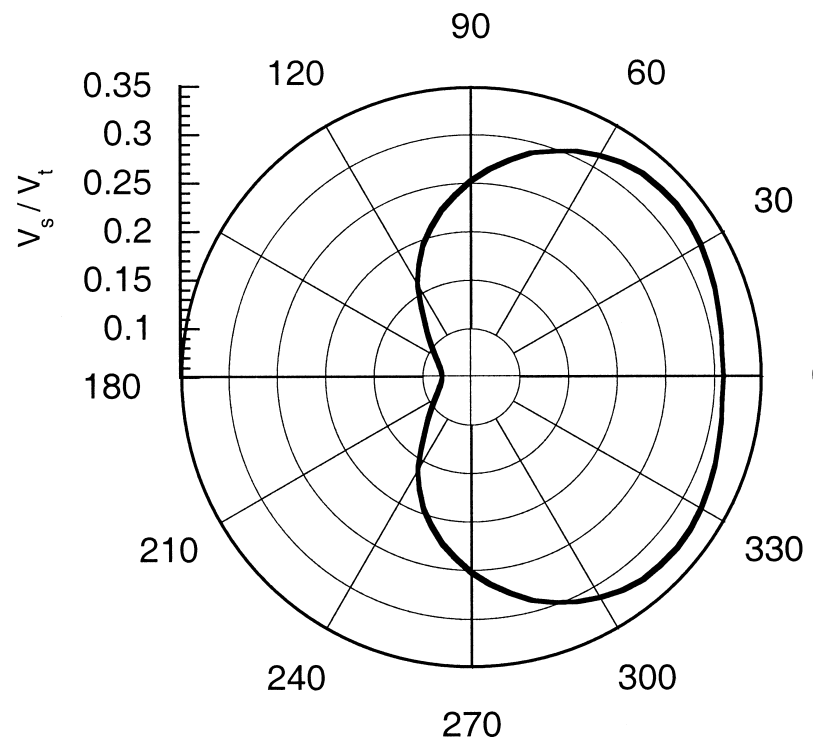

FIG. A3. The function $V_{s} / V_{t}$ (with $C=0.1$ ) modified by assuming that the ship tacked for $\delta>120$. See text for details.
The function $V / V$ requires one modification before it can be used to compute ship motion from observed winds. As seen in Figs. A1 and A2, forward speed decreases rapidly (and eventually drops to zero) for $\delta>120^{\circ}$. However, a ship does not cease moving upon encountering headwinds; instead, it can tack in order to sail into the wind. Figure A3 shows $V_{s} / V_{t}$ modified by assuming that the ship tacked whenever $\delta>120^{\circ}$ so as to keep the wind no closer than $60^{\circ}$ to the bow. Now, rather than dropping to zero, forward progress is still possible albeit at relatively low speed. Thus modified, the function (1) was used in all our estimates of travel time based upon NCEP winds, after setting $\alpha=0.89$ to "normalize" the mean travel time obtained from NCEP data ( 82.5 days) to the mean travel time derived from the historical data $(92.48$ days).

\section{References}

Bradley, R. S., and P. D. Jones, Eds., 1992: Climate Since A.D. 1500. Routledge, $679 \mathrm{pp}$.

Burt, W. V., 1990: The search for the Manila galleon log books. Bull. Amer. Meteor. Soc., 71, 1630-1636.

$\mathrm{Fu}, \mathrm{C}$, and J. Fletcher, 1988: Large signals of climatic variation over the ocean in the Asian monsoon region. Adv. Atmos. Sci., 5, 389-404.

García, Herrera, R., M. R. Prieto, L. Gimeno, E. Hernández, E. López, and E. Herrera, 1999: The Archivo General de Indias as a source of climatic marine surface information. WMO Marine Meteorology and Related Oceanographic Activities, H. Diaz and S. Woodruff, Eds., WMO Rep. 43, WMO/TD 957, 61-69.

Garrett, R., 1996: The Symmetry of Sailing. Sheridan House, $268 \mathrm{pp}$.

Kalnay, E., and Coauthors, 1996: The NCEP/NCAR 40-Year Reanalysis Project. Bull. Amer. Meteor. Soc., 77, 437-471.

Kaplan, A., Y. Kushnir, and M. A. Cane, 2000: Reduced space optimal interpolation of historical marine sea level pressure: 1854-1992. J. Climate, 13, 2987-3002.

Kistler, R., and Coauthors, 2001: The NCEP/NCAR 50-year reanalysis: Monthly means CD-ROM and documentation. Bull. Amer. Meteor. Soc., 82, 152-168.

Kripalani, R. H., and A. Kilkarni, 1997: Rainfall variability over south-east Asia-Connections with Indian monsoon and ENSO extremes: New perspectives. Int. J. Climatol., 17, $1155-1168$.

Lau, K.-M., and S. Yang, 1997: Climatology and interannual variability of the Southeast Asian summer monsoon. $A d v$. Atmos. Sci., 14, 141-162.

— , and Coauthors, 2000: A report of the field operations and early results of the South China Sea Monsoon Experiment (SCMEX). Bull. Amer. Meteor. Soc., 81, 1261-1270.

McGregor, G. R., and S. Nieuwolt, 1998: Tropical Climatology. John Wiley and Sons, 339 pp. 
Meehl, G. A., 1982: Characteristics of surface current flow inferred from a global ocean current data set. J. Phys. Oceanogr., 12, 538-555.

Ortlieb, L., 2000: The documentary historical record of El Niño events in Peru: An update of the Quinn record (sixteenth through nineteenth centuries). El Niño and the Southern Oscillation, Multiscale Variability and Global and Regional Impacts, H. F. Díaz and V. Markgraf, Eds., Cambridge University Press, 207-295.

Parthasarathy, B., K. Rupa Kumar, and A. A. Munot, 1991: Evidence of secular variations in Indian monsoon rainfallcirculation relationships. J. Climate, 4, 927-938.

Prieto, M. R., R. Herrera, and P. Dussel, 1999: Historical evidences of Mendoza River, Argentina, streamflow fluctuations and their relationship with ENSO. Holocene, 9, 473-481.

Quinn, W. H., 1992: A study of Southern Oscillation-related climatic activity for A.D. 622-1990 incorporating Nile River flood data. El Niño: Historical and Paleoclimatic Aspects of the Southern Oscillation, H. Díaz and V. Markgraf, Eds., Cambridge University Press, 119-150.

— , D. O. Zorf, K. S. Short, and R. T. Kuo Yang, 1978: Historical trends and statistics of the Southern Oscillation,
El Niño, and Indonesian droughts. Fish. Bull. U.S., 76, 663678.

Ramage, C. S., 1971: Monsoon Meteorology. Academic Press, 296 pp.

Sadler, J. C., M. A. Lander, A. M. Horei, and L. K. Oda, 1987: Tropical Marine Climatic Atlas. UHMET Publ. 87-02, Dept. of Meteorology, University of Hawaii.

Santiago, Cruz, F., 1962: La Nao de China. Jus, 191 pp.

Schurz, W. L., 1939: The Manila Galleon. E. P. Dutton and Company, $453 \mathrm{pp}$.

Serrano Mangas, F., 1985: Los galeones de la carrera de Indias, 1650-1700. Publ. Escuela de Estudios Hispano-Americanos de Sevilla, CCCXVII, 1-209.

Tao, S., and L. Chen, 1987: A review of recent research on the East Asian summer monsoon in China. Monsoon Meteorology, C.-P. Chang and T. N. Krishnamurti, Eds., Oxford University Press, 60-92.

Williams, J. H., 1982: Tapping the Orient: Voyages of the Manila galleons. Oceans, 15, 44-49.

Woodruff, S. D., R. J. Slutz, R. L. Jenne, and P. M. Steurer, 1987: A comprehensive ocean-atmosphere data set. Bull. Amer. Meteor. Soc., 68, 1239-1250.

\section{Call for Weather-Related Art and Photos}

The Bulletin of the American Meteorological Society invites submission of original, weather-related art and photos for potential publication in future issues of the magazine. The Bulletin staff is especially interested in work that is artistic and creative, featuring a unique, interesting perspective; chosen works will be used to help add more graphic appeal to the Bulletin. Specific use of the images will be determined by the production staff. Please be aware that your submission will not be peer reviewed-we will be looking at submissions more from an aesthetic viewpoint than a scientific one. (Photos intended for scientific publication should be submitted following normal Bulletin guidelines for peer-reviewed submissions.) Nonetheless, all submissions will be given equal consideration.

We hope that you will take this ongoing opportunity to inspire your colleagues and shape the look of your Society's publication. Ownership of the works will be retained by the artist/photographer; we do not offer payment for published submissions.

Submission requirements: For artwork, please do not submit the original work of art-send only a high-quality color photo of the piece. For art and all other photographs submitted for consideration, send only first-quality, camera-ready prints or slides (no photocopies, please). Submissions will not be returned unless accompanied by a self-addressed envelope with correct postage.

Please include with the submission your name, the title of the work (if applicable), and any other relevant information. If a description of the submission would be helpful, please include a succinct caption.

Please submit your work to: David Gershman, Manager of Art and Design, AMS, 45 Beacon St., Boston, MA 02108-3693. 